\title{
Cadmium uptake by algal biomass in batch and continuous (CSTR and packed bed column) adsorbers
}

\author{
Vítor J.P. Vilar ${ }^{\mathrm{a}}$, Sílvia C.R. Santos ${ }^{\mathrm{a}}$, Ramiro J.E. Martins ${ }^{\mathrm{b}}$, \\ Cidália M.S. Botelho ${ }^{a}$, Rui A.R. Boaventura ${ }^{\mathrm{a}, *}$ \\ a LSRE-Laboratory of Separation and Reaction Engineering, Department of Chemical Engineering, Faculty of Engineering, \\ University of Porto, Rua Dr. Roberto Frias, 4200-465 Porto, Portugal \\ ${ }^{\mathrm{b}}$ Department of Chemical Technology, Superior School of Technology, Polytechnic Institute of Bragança, \\ Campus de Santa Apolónia, 5301-857 Bragança, Portugal
}

\begin{abstract}
A B S T R A C T
In this work, the properties of marine algae Gelidium, algal waste from agar extraction industry and a composite material were investigated for cadmium(II) biosorption. Equilibrium experiments were performed at three $\mathrm{pH}$ values $(4,5.3$ and 6.5$)$. Equilibrium data were well described by the Langmuir and Langmuir-Freundlich isotherms. Two models predicting the $\mathrm{pH}$ influence in the cadmium biosorption (discrete and continuous models) have been developed in order to better describe the equilibrium. The continuous model also considers a heterogeneous distribution of carboxylic groups, determined by potentiometric titration. The results of batch kinetic experiments performed at different $\mathrm{pH}$ values were well fitted by two mass transfer models and the homogeneous diffusion coefficients for the cadmium ions inside the biosorbent were obtained. Continuous stirred tank reactor (CSTR) and packed bed column configurations were also examined for the biosorption of cadmium ions. A strong acid $\left(0.1 \mathrm{M} \mathrm{HNO}_{3}\right)$ was used as eluant to regenerate the biosorbents in the column. Several mass transfer models were applied with success to describe the biosorption process in batch mode, CSTR and fixed bed column.
\end{abstract}

\section{Introduction}

The two major sources of environmental contamination by cadmium are the production and consumption of cadmium and other non-ferrous metals and the disposal of wastes containing cadmium. Areas in the vicinity of non-ferrous mines and smelters often show pronounced cadmium contamination. The principal applications of cadmium fall into five categories: protective plating on steel, stabilizers for poly-vinyl chloride (PVC), pigments in plastics and glasses, electrode material in nickel-cadmium batteries, and as a component of various alloys [1,2].

Biosorption of metal ions by various biological materials has been studied extensively in the last decade due to its potential for wastewater treatment $[3,4]$. Different dead biomass types, such as bacteria [5,6], fungi [7], blue-green algae [8], green algae [9], red algae [10], brown algae [11-13], peat biomass [14], chitosan [15], aquatic mosses [16], tree fern [17], waste brewery biomass [18] and many other low-cost biosorbents have been applied to remove cadmium ions from solution.

Considerable work carried out with seaweeds, especially with brown algae (Sargassum fluitans, Ascophyllum nodosum and others), have shown their capacity to bind cadmium, copper, nickel, lead, and zinc cations up to $20 \%$ of the biosorbent dry weight [19]. Metal uptake is possible due to electrostatic interactions (attractions) between metal cations and negatively charged sites at the cell surface [3].

To apply these low-cost adsorbents in an industrial process, continuous flow studies need to be performed. Biosorption in packed bed column has been widely investigated and seems to represent the most effective operating system [20-26]. Nevertheless, CSTR (continuous stirred tank reactor) allows handling suspensions, permits the combination of flow schemes and does not need immobilization of the biomass to maintain the integrity of the adsorbent particles, if there is a biosorbent filtration step. Polyacrylonitrile has been proposed for the preparation of granular forms of powdered materials, such as algal wastes, with regard to their application in environmental technologies [27,28].

This paper evaluates the effect of $\mathrm{pH}$, ionic strength and temperature on the adsorption capacity of three different biosorbents, compares their adsorption capacity based on the model 


\begin{tabular}{|c|c|}
\hline \multicolumn{2}{|c|}{ Nomenclature } \\
\hline$a_{\mathrm{p}}$ & specific area for thin plates particles \\
\hline$C_{\mathrm{b}}$ & $\begin{array}{l}\text { metal concentration in the bulk ( } \mathrm{mg} \text { or } \mathrm{mmol} \\
\text { metal/l fluid) }\end{array}$ \\
\hline$C_{b_{0}}$ & $\begin{array}{l}\text { initial metal concentration in the bulk ( } \mathrm{mg} \text { or } \mathrm{mmol} \\
\text { metal/l fluid) }\end{array}$ \\
\hline$C_{\mathrm{E}}$ & feed concentration (mg or mmol metal/l fluid) \\
\hline$C_{\mathrm{f}}$ & $\begin{array}{l}\text { metal concentration in the film ( } \mathrm{mg} \text { or } \mathrm{mmol} \\
\text { metal/l fluid) }\end{array}$ \\
\hline$C_{\text {final }}$ & $\begin{array}{l}\text { metal concentration in the solution at the end of } \\
\text { the saturation or elution process ( } \mathrm{mg} \text { or mmol } \\
\text { metal/l fluid) }\end{array}$ \\
\hline$C_{\mathrm{CI}}$ & $\begin{array}{l}\text { initial metal concentration in the solution (elution } \\
\text { process) (mmol metal/l fluid) }\end{array}$ \\
\hline$C_{\mathrm{H}}$ & $\begin{array}{l}\text { equilibrium concentration of proton in the fluid } \\
\text { phase (mmol proton/l fluid) }\end{array}$ \\
\hline$C_{\mathrm{M}}$ & $\begin{array}{l}\text { equilibrium concentration of metal in the fluid } \\
\text { phase (mmol metal/l fluid) }\end{array}$ \\
\hline$C_{\mathrm{T}}$ & $\begin{array}{l}\text { total (cadmium }+ \text { acid) liquid concentration } \\
\text { (mmol/l fluid) }\end{array}$ \\
\hline$C_{\mathrm{T}_{0}}$ & $\begin{array}{l}\text { initial total (cadmium }+ \text { acid) liquid concentration } \\
\text { (mmol/l fluid) }\end{array}$ \\
\hline$C_{\mathrm{T}_{\mathrm{E}}}$ & total feed (acid) liquid concentration ( $\mathrm{mmol} / \mathrm{l}$ fluid) \\
\hline$D_{\mathrm{ax}}$ & axial dispersion coefficient $\left(\mathrm{cm} \mathrm{s}^{-1}\right)$ \\
\hline$D_{\mathrm{h}}$ & homogeneous diffusion coefficient $\left(\mathrm{cm}^{2} \mathrm{~s}^{-1}\right)$ \\
\hline$\Delta G^{\circ}$ & Gibbs free energy of biosorption (J/mol) \\
\hline$\Delta H^{\circ}$ & $\begin{array}{l}\text { enthalpy of the adsorption process given by } \\
\text { Clausius-Clapeyron relationship }(\mathrm{J} / \mathrm{mol})\end{array}$ \\
\hline IS & ionic strength $(\mathrm{M})$ \\
\hline$k_{\mathrm{f}}$ & film mass transfer coefficient $\left(\mathrm{cm} \mathrm{s}^{-1}\right)$ \\
\hline$k_{\mathrm{p}}$ & $\begin{array}{l}\text { mass transfer coefficient for intraparticle diffusion } \\
\left(\mathrm{cm} \mathrm{s}^{-1}\right)\end{array}$ \\
\hline$K_{\mathrm{H}}$ & equilibrium proton constant (1 fluid/mmol proton) \\
\hline$K_{\mathrm{M}}$ & equilibrium metal constant (1 fluid/mmol metal) \\
\hline$K_{\mathrm{H}}^{\prime}$ & $\begin{array}{l}\text { average value of the affinity constant distribution } \\
\text { for the proton (l fluid/mmol proton) }\end{array}$ \\
\hline$K_{\mathrm{M}}^{\prime}$ & $\begin{array}{l}\text { average value of the affinity constant distribution } \\
\text { for the metal (l fluid/mmol metal) }\end{array}$ \\
\hline$K_{\mathrm{L}}$ & equilibrium constant of Langmuir (1 fluid/mg metal) \\
\hline & $\begin{array}{l}\text { equilibrium constant of Langmuir-Freundlich } \\
\text { (lfluid/mg metal) }\end{array}$ \\
\hline$K_{\mathrm{H}}^{\mathrm{M}}$ & $\begin{array}{l}\text { selectivity coefficient between metal ion in the par- } \\
\text { ticle and proton in solution }\end{array}$ \\
\hline$L$ & bed length $(\mathrm{cm})$ \\
\hline$n$ & empirical dimensionless parameter \\
\hline \multicolumn{2}{|c|}{$\begin{array}{l}n_{\mathrm{M}} \text { and } n_{\mathrm{H}} \text { constants that reflect the overall non-ideality of } \\
\text { metal and proton }\end{array}$} \\
\hline$N_{\mathrm{d}}$ & $\begin{array}{l}\text { number of mass transfer units by intraparticle dif- } \\
\text { fusion }\end{array}$ \\
\hline$N_{\mathrm{f}}$ & number of mass transfer units by film diffusion \\
\hline$p$ & $\begin{array}{l}\text { represents the intrinsic heterogeneity of the biosor- } \\
\text { bent }\end{array}$ \\
\hline $\mathrm{Pe}$ & axial Peclet number based on the bed length \\
\hline & $\begin{array}{l}\text { axial Peclet number based on the particle diameter } \\
\text { (spherical) or width (thin plate) }\end{array}$ \\
\hline $\mathrm{pH}_{\mathrm{SE}}$ & $\mathrm{pH}$ of feed solution \\
\hline $\mathrm{pH}_{\mathrm{AI}}$ & $\begin{array}{l}\text { initial } \mathrm{pH} \text { of interstitial fluid inside the adsorber } \\
\text { (CSTR) }\end{array}$ \\
\hline $\mathrm{pH}_{\mathrm{CI}}$ & initial $\mathrm{pH}$ of interstitial fluid inside the column \\
\hline $\mathrm{pH}_{\mathrm{AE}}$ & $\begin{array}{l}\text { final } \mathrm{pH} \text { of interstitial fluid inside the adsorber } \\
\text { (CSTR) }\end{array}$ \\
\hline $\mathrm{pH}_{\mathrm{CE}}$ & final $\mathrm{pH}$ of interstitial fluid inside the column \\
\hline
\end{tabular}

\begin{tabular}{|c|c|}
\hline$\langle q\rangle$ & $\begin{array}{l}\text { average metal concentration in the solid phase ( } \mathrm{mg} \\
\text { or mmol metal/g biomass) }\end{array}$ \\
\hline$q_{\mathrm{E}}$ & $\begin{array}{l}\text { solid phase concentration in equilibrium with } C_{\mathrm{E}} \\
\text { (mg or mmol metal/g biomass) }\end{array}$ \\
\hline$q_{\mathrm{H}}$ & $\begin{array}{l}\text { equilibrium concentration of proton in the biomass } \\
\text { (mmol metal/g biomass) }\end{array}$ \\
\hline$q_{\mathrm{L}}$ e $q_{\mathrm{LF}}$ & $\begin{array}{l}\text { maximum amount of metal per g of adsorbent of } \\
\text { Langmuir (L) and Langmuir-Freundlich (LF) equa- } \\
\text { tions (mg metal/l) }\end{array}$ \\
\hline$q_{\mathrm{M}}$ & $\begin{array}{l}\text { equilibrium concentration of metal in the biomass } \\
\text { (mg or mmol metal/g biomass) }\end{array}$ \\
\hline$q_{\mathrm{M}_{0}}$ & $\begin{array}{l}\text { metal concentration in the solid phase in equilib- } \\
\text { rium with } C_{\mathrm{b}_{\mathrm{o}}} \text { ( } \mathrm{mg} \text { or } \mathrm{mmol} \text { metal/g biomass) }\end{array}$ \\
\hline$q_{t}$ & $\begin{array}{l}\text { concentration of ion species in the sorbent at time } t \\
\text { (mg metal/g biosorbent) }\end{array}$ \\
\hline$Q_{\max }$ & $\begin{array}{l}\text { concentration of carboxylic groups or maximum } \\
\text { capacity of biomass ( } \mathrm{mg} \text { or } \mathrm{mmol} \mathrm{g}^{-1} \text { biomass) }\end{array}$ \\
\hline$r$ & $\begin{array}{l}\text { the dimensionless axial coordinate inside the parti- } \\
\text { cle }\end{array}$ \\
\hline$R$ & the distance to the symmetry plane $(\mathrm{cm})$ \\
\hline$R_{0}$ & half of thickness of the thin plate $(\mathrm{cm})$ \\
\hline Sh & Sherwood number \\
\hline$\Delta S^{\circ}$ & $\begin{array}{l}\text { entropy of the system given by the van't Hoff equa- } \\
\text { tion }(\mathrm{J} / \mathrm{mol} \mathrm{K})\end{array}$ \\
\hline$t$ & time $(\mathrm{s})$ \\
\hline$t_{\mathrm{b}}$ & breakthrough time (s) \\
\hline$t_{\mathrm{st}}$ & stoichiometric time $(\mathrm{s})$ \\
\hline$T$ & temperature $\left({ }^{\circ} \mathrm{C}\right)$ \\
\hline$u_{\mathrm{i}}$ & interstitial fluid velocity $\left(\mathrm{cm} \mathrm{s}^{-1}\right)$ \\
\hline$V$ & metal solution volume (1) \\
\hline$V_{\mathrm{r}}$ & volume of the adsorber (CSTR) (ml) \\
\hline W & mass of biosorbent $(\mathrm{g})$ \\
\hline$y$ or $x$ & dimensionless concentration in the solid phase \\
\hline$\langle y\rangle$ or $\langle x\rangle$ & $\begin{array}{l}\text { dimensionless average concentration in the solid } \\
\text { phase }\end{array}$ \\
\hline$y_{\mathrm{b}}$ or $x_{\mathrm{b}}$ & dimensionless concentration in the fluid phase \\
\hline & $\begin{array}{l}\text { dimensionless concentration in the fluid phase at } \\
\text { the film }\end{array}$ \\
\hline$y_{\mathrm{T}}$ & dimensionless total concentration in the fluid phase \\
\hline$y^{*}$ or $x^{*}$ & $\begin{array}{l}\text { dimensionless concentration in the solid phase at } \\
\text { the particle surface }\end{array}$ \\
\hline$z$ & bed axial position $(\mathrm{cm})$ \\
\hline \multicolumn{2}{|c|}{ Greek letters } \\
\hline$\varepsilon$ & porosity of the bed \\
\hline$\theta$ & dimensionless time \\
\hline$\rho_{\text {ap }}$ & apparent density of particles (g solid $/ \mathrm{cm}^{3}$ particle) \\
\hline$\tau$ & space time $(\mathrm{s})$ \\
\hline$\tau_{\mathrm{d}}$ & time constant for intraparticle diffusion \\
\hline$\tau_{\mathrm{f}}$ & time constant for film diffusion \\
\hline$\xi$ & the adsorber capacity factor \\
\hline$\zeta$ & axial position normalized by the bed length \\
\hline
\end{tabular}

parameters, and compares the biosorption performance in batch and continuous mode using a CSTR and a packed bed column.

\section{Theory}

\subsection{Discrete equilibrium model}

A mathematical equilibrium model has been developed assuming one kind of active sites (carboxylic groups) in the cell wall, 
responsible for metal biosorption for $\mathrm{pH}<7$, and competition between metal ions and protons [29]. The model is based on apparent equilibrium binding constants, $K_{\mathrm{H}}$ and $K_{\mathrm{M}}$ for $\mathrm{H}^{+}$and $\mathrm{M}^{2+}$, respectively. The total metal uptake $\left(q_{\mathrm{M}}\right)$ can be calculated as:

$q_{\mathrm{M}}=\frac{Q_{\max } K_{\mathrm{M}} C_{\mathrm{M}}}{1+K_{\mathrm{H}} C_{\mathrm{H}}+K_{\mathrm{M}} C_{\mathrm{M}}}$

where $Q_{\max }$ is the maximum amount of binding sites (carboxylic groups) (mmol g-1) and $C_{\mathrm{H}}$ and $C_{\mathrm{M}_{i}}$ are the equilibrium concentrations for protons $(\mathrm{H})$ and divalent metal ions $(\mathrm{M})$, respectively.

This equation can be converted to a Langmuir-type equation dividing by $\left(1+K_{\mathrm{H}} C_{\mathrm{H}}\right)$ :

$q_{\mathrm{M}}=\frac{Q_{\max } K_{\mathrm{L}}^{\prime} C_{\mathrm{M}}}{1+K_{\mathrm{L}}^{\prime} C_{\mathrm{M}}}, \quad K_{\mathrm{L}}^{\prime}=\frac{K_{\mathrm{M}}}{1+K_{\mathrm{H}} C_{\mathrm{H}}}$

From $K_{\mathrm{M}}$ and $K_{\mathrm{H}}$ values it is possible to calculate the equilibrium constant $\left(K_{\mathrm{L}}^{\prime}\right)$ for each $\mathrm{pH}\left(\mathrm{pH}=\log C_{\mathrm{H}}\right)$.

The Langmuir (L) [30] and Langmuir-Freundlich (LF) [31] equilibrium models are represented by the following equations, respectively:

$q_{\mathrm{M}}=\frac{q_{\mathrm{L}} K_{\mathrm{L}} C_{\mathrm{M}}}{1+K_{\mathrm{L}} C_{\mathrm{M}}}$

and

$q_{\mathrm{M}}=\frac{q_{\mathrm{LF}} K_{\mathrm{LF}}\left(C_{\mathrm{M}}\right)^{\left(1 / n_{\mathrm{LF}}\right)}}{1+K_{\mathrm{LF}}\left(C_{\mathrm{M}}\right)^{\left(1 / n_{\mathrm{LF}}\right)}}$

where $q_{\mathrm{L}}$ and $q_{\mathrm{LF}}$ (mg or $\mathrm{mmolg}^{-1}$ ) are the maximum amount of the metal per unit weight of biosorbent of the $L$ and LF equations, respectively, and $K_{\mathrm{L}}\left(\mathrm{mg}^{-1}\right)$ and $K_{\mathrm{LF}}\left(1^{1 / n} \mathrm{mg}^{-1 / n}\right)$ are the equilibrium constants of the $\mathrm{L}$ and LF equations, respectively, and $n$ is an empirical parameter of the LF equation.

\subsection{Continuous equilibrium model}

For an adsorbent with heterogeneous active sites, assuming competition between metal ions and protons, and that cadmium biosorption occurs only on carboxylic groups ( $\mathrm{pH}<7$ ), the continuous model is defined as [32]:

$q_{\mathrm{M}}=Q_{\max } \frac{n_{\mathrm{M}}}{n_{\mathrm{H}}} \frac{\left(K_{\mathrm{M}}^{\prime} C_{\mathrm{M}}\right)^{n_{\mathrm{M}}}\left\{\left(K_{\mathrm{H}}^{\prime} C_{\mathrm{H}}\right)^{n_{\mathrm{H}}}+\left(K_{\mathrm{M}}^{\prime} C_{\mathrm{M}}\right)^{n_{\mathrm{M}}}\right\}^{p-1}}{1+\left\{\left(K_{\mathrm{H}}^{\prime} C_{\mathrm{H}}\right)^{n_{\mathrm{H}}}+\left(K_{\mathrm{M}}^{\prime} C_{\mathrm{M}}\right)^{n_{\mathrm{M}}}\right\}^{p}}$

where $K_{\mathrm{X}}^{\prime}$ is the average value of the affinity constants distribution for species X (M-metal or H-proton), and $n_{\mathrm{M}}$ and $n_{\mathrm{H}}$ reflect the overall non-ideality which can be due to lateral interactions and/or stoichiometry effects. The effect of the groups intrinsic heterogeneity $(p)$ can be isolated from the non-ideal behaviour of metal and proton $\left(n_{\mathrm{M}}\right.$ and $\left.n_{\mathrm{H}}\right)$, since $m_{i}=n_{i} \times p$.

\subsection{Mass transfer models in batch system}

For quantitative description of the biosorption process dynamics, the following assumptions are made: the effect of the external film diffusion on the biosorption rate is negligible when using adequate stirring; the sorption rate is controlled by homogeneous diffusion inside the particle or by linear driving force (LDF); the biosorption process is isothermal and equilibrium exists between bound and dissolved metal ions, as formulated by the Langmuir isotherm; particles are uni-dimensional thin plates. The concentration profiles inside the particle can be predicted either by the Homogeneous Diffusion Model or by the linear driving force model, but the last one can be analytically solved $[33,34]$.

\subsubsection{Homogeneous Diffusion Model}

Mass conservation inside the particles

$\frac{\partial x(r, t)}{\partial t}=\frac{1}{\tau_{\mathrm{d}}} \frac{\partial^{2} x(r, t)}{\partial r^{2}} ; \quad \tau_{\mathrm{d}}=\frac{R_{0}^{2}}{D_{\mathrm{h}}}$

The initial and boundary conditions for Eq. (6) are:

$$
\begin{array}{ccc}
t=0 & \begin{array}{c}
x_{\mathrm{b}}(0)=1 \\
0 \leq r<1 \quad x(r, 0)=0
\end{array} \\
& r=1 \quad x^{*}(0)=\frac{K_{\mathrm{L}} C_{\mathrm{b}_{0}}}{1+K_{\mathrm{L}} C_{\mathrm{b}_{0}}} \\
r=0 & \frac{\partial x(r, t)}{\partial r}=0 \quad \forall t \\
r=1 & \frac{\partial x(r, t)}{\partial t}=-\frac{\xi}{\tau_{d}} K_{\mathrm{L}} C_{\mathrm{b}_{0}}[1-x(r, t)]^{2}\left[\frac{\partial x(r, t)}{\partial r}\right]_{r=1} \forall t
\end{array}
$$

Dimensionless variables:

$$
\begin{aligned}
& x_{\mathrm{b}}(t)=\frac{C_{\mathrm{b}}(t)}{C_{\mathrm{b}_{0}}} ; \quad x(r, t)=\frac{q(R, t)}{Q_{\max }} ; \quad\langle x(r, t)\rangle=\frac{\langle q(R, t)\rangle}{Q_{\max }} ; \quad r=\frac{R}{R_{0}} ; \\
& x^{*}(t)=\frac{q_{\mathrm{M}}(t)}{Q_{\max }} ; \quad \xi=\frac{W Q_{\max }}{V C_{\mathrm{b}_{0}}}
\end{aligned}
$$

A collocation on finite elements method [35] was used to solve the non-linear parabolic partial differential equations (PDE) with the initial and boundary conditions for each model equation.

\subsubsection{Linear driving force model (LDF)}

If the average metal concentration inside the particle is considered, instead of a concentration profile, the following equations are obtained:

Kinetic law:

$\frac{\mathrm{d}\langle x(t)\rangle}{\mathrm{d} t}=k_{\mathrm{p}} a_{\mathrm{p}}\left[x^{*}(t)-\langle x(t)\rangle\right] \quad ; k_{\mathrm{p}} a_{\mathrm{p}}=\frac{D_{\mathrm{h}}}{\phi R_{0}^{2}}=\frac{3}{\tau_{d}} ; \quad \phi=\frac{1}{3} ;$

$a_{\mathrm{p}}=\frac{1}{R_{0}}$

Mass conservation in the fluid inside the closed vessel:

$\langle x(t)\rangle=\frac{1}{\xi}\left(1-x_{\mathrm{b}}(t)\right)$

Initial condition:

$t=0 x_{\mathrm{b}}(t)=1,\langle x(t)\rangle=0$

Rearranging Eqs. (10) and (11) the following expression is obtained that can be solved analytically using the initial conditions of Eq. (12):

$\frac{1}{k_{\mathrm{p}} a_{\mathrm{p}}} \frac{\mathrm{d} x_{\mathrm{b}}(t)}{\mathrm{d} t}+\left(\frac{\xi K_{\mathrm{L}} C_{\mathrm{b}_{0}}}{1+K_{\mathrm{L}} C_{\mathrm{b}_{0}} x_{\mathrm{b}}(t)}+1\right) x_{\mathrm{b}}(t)=1$

\subsection{Mass transfer model in CSTR adsorber}

A model was developed with the following assumptions: isothermal operation, adsorption equilibrium described by the Langmuir isotherm, external (film) resistance to mass transfer, and internal mass transfer resistance described by the LDF approximation. The model equations are [36]:

Mass conservation in the fluid around particles

$\frac{\mathrm{d} y_{\mathrm{b}}(\theta)}{\mathrm{d} \theta}=1-y_{\mathrm{b}}(\theta)-\xi \frac{\mathrm{d}\langle y(\theta)\rangle}{\mathrm{d} \theta}$ 
Mass conservation inside particles (linear driving force)

$\frac{\mathrm{d}\langle y(\theta)\rangle}{\mathrm{d} \theta}=N_{\mathrm{d}}\left(y^{*}(\theta)-\langle y(\theta)\rangle\right)$

Assuming that there is no accumulation in the fluid film surrounding particles, we can write:

$\frac{\mathrm{d}\langle y(\theta)\rangle}{\mathrm{d} \theta}=\frac{N_{\mathrm{f}}}{\xi}\left(y_{\mathrm{b}}(\theta)-y_{\mathrm{f}}(\theta)\right)$

Equalling Eq. (15) to Eq. (16) we will get:

$\frac{N_{\mathrm{f}}}{\xi}\left(y_{\mathrm{b}}(\theta)-y_{\mathrm{f}}(\theta)\right)=N_{\mathrm{d}}\left[y^{*}(\theta)-\langle y(\theta)\rangle\right]$

Initial conditions can be set as,

$\theta=0 y_{\mathrm{b}}(\theta)=0, y_{\mathrm{f}}(\theta)=0,\langle y(\theta)\rangle=0$

The dimensionless variables are:

$y_{\mathrm{b}}(\theta)=\frac{C_{\mathrm{b}}(t)}{C_{\mathrm{E}}}, \quad y_{\mathrm{f}}(\theta)=\frac{C_{\mathrm{f}}(t)}{C_{\mathrm{E}}}, \quad\langle y(\theta)\rangle=\frac{\langle q(t)\rangle}{q_{\mathrm{E}}}, \quad y^{*}(\theta)=\frac{q_{\mathrm{M}}(t)}{q_{\mathrm{E}}}$

and the dimensionless parameters are:

$\tau=\frac{\varepsilon V_{r}}{Q}, \quad \tau_{\mathrm{d}}=\frac{R_{0}^{2}}{D_{\mathrm{h}}}, \quad \tau_{\mathrm{d}}^{*}=\frac{1}{k_{\mathrm{p}} a_{\mathrm{p}}}=\frac{\tau_{\mathrm{d}}}{3}, \quad \tau_{\mathrm{f}}=\frac{\varepsilon}{(1-\varepsilon)} \frac{1}{k_{\mathrm{f}} a_{\mathrm{p}}}$, $\xi=\frac{(1-\varepsilon)}{\varepsilon} \rho_{\mathrm{ap}} \frac{q_{\mathrm{E}}}{C_{\mathrm{E}}}, \quad N_{\mathrm{f}}=\frac{\tau}{\tau_{\mathrm{f}}}=\frac{(1-\varepsilon)}{\varepsilon} k_{\mathrm{f}} a_{\mathrm{p}} \tau, \quad N_{\mathrm{d}}=\frac{\tau}{\tau_{\mathrm{d}}^{*}}=k_{\mathrm{p}} a_{\mathrm{p}} \tau$

where $q_{\mathrm{E}}=Q_{\max } K_{\mathrm{L}} C_{\mathrm{E}} /\left[1+K_{\mathrm{L}} C_{\mathrm{E}}\right]$ is the solid phase concentration in equilibrium with $C_{\mathrm{E}}$.

The system of Eqs. (14) and (15) in conjunction with the initial conditions (Eq. (18)), was solved by Livermore Solver for Ordinary Differential Equations (LSODA) subroutine [37], where $y_{\mathrm{f}}$ is obtained by solving Eq. (17) and the equilibrium is given by the Langmuir isotherm.

\subsection{Mass transfer models in packed bed column}

\subsubsection{Saturation}

The saturation model was developed with the following assumptions: isothermal operation, axial dispersed plug flow of the fluid phase, adsorption equilibrium described by the Langmuir isotherm, external (film) resistance to mass transfer, and internal mass transfer resistance described by the LDF approximation. We present below the dimensionless equations of the mass transfer model [33,34].

Mass conservation in the fluid around particles:

$$
\frac{\partial y_{\mathrm{b}}(\zeta, \theta)}{\partial \theta}=\frac{1}{P e} \frac{\partial^{2} y_{\mathrm{b}}(\zeta, \theta)}{\partial \zeta^{2}}-\frac{\partial y_{\mathrm{b}}(\zeta, \theta)}{\partial \zeta}-\xi N_{\mathrm{d}}\left[y^{*}(\zeta, \theta)-\langle y(\zeta, \theta)\rangle\right]
$$

with the initial and boundary conditions:

$$
\begin{aligned}
& \theta=0 y_{\mathrm{b}}(\zeta, 0)=y_{\mathrm{f}},(\zeta, 0)=\langle y(\zeta, 0)\rangle=0 \\
& \zeta=0-\frac{1}{P e} \frac{\partial y_{\mathrm{b}}(\zeta, \theta)}{\partial \zeta}+y_{\mathrm{b}}(\zeta, \theta)=1 \\
& \zeta=\left.1 \frac{\partial y_{\mathrm{b}}(\zeta, \theta)}{\partial \zeta}\right|_{\zeta=1}=0
\end{aligned}
$$

The new dimensionless variables are defined as:

$$
\zeta=\frac{z}{L}, \quad\langle y(\zeta, \theta)\rangle=\frac{\langle q(z, t)\rangle}{q_{\mathrm{E}}}, \quad y^{*}(\zeta, \theta)=\frac{q_{\mathrm{M}}(z, t)}{q_{\mathrm{E}}}
$$

And the new dimensionless parameters as:

$\tau=\frac{L}{u_{i}}, \quad P e=\frac{u_{i} L}{D_{\mathrm{ax}}}$

The partial differential Eq. (19) and ordinary differential equation (ODE) Eq. (15) in conjunction with the initial and boundary conditions, Eqs. (20-22), were solved by the General Collocation Software for Partial Differential Equations (PDECOL) package [35], where $y_{\mathrm{f}}(\zeta, \theta)$ is obtained by solving Eq. (17) and the equilibrium is given by the Langmuir isotherm.

\subsubsection{Regeneration}

The desorption mechanism was shown to be considered as an ion exchange between metal ions and protons with a $1: 1$ stoichiometry and equilibrium was well described by the mass action law [38]:

$y^{*}=\frac{K_{\mathrm{H}}^{\mathrm{M}} y_{\mathrm{f}}(\zeta, \theta)}{y_{\mathrm{T}}(\zeta, \theta)+\left(K_{\mathrm{H}}^{\mathrm{M}}-1\right) y_{\mathrm{f}}(\zeta, \theta)}$

where $K_{\mathrm{H}}^{\mathrm{M}}$ and $Q_{\max }$ values are 0.93 and 1.1, 0.36 and $0.16 \mathrm{mmol} \mathrm{g}^{-1}$, respectively, for algae Gelidium and composite material [38].

A model has been developed using the mass action law to describe equilibrium, in order to simulate the elution experiment. So, Eqs. (15), (16) and (21) are still valid if the concentrations in the liquid and solid phase are expressed in $\mathrm{mmoll}^{-1}$ instead of $\mathrm{mg} \mathrm{l}^{-1}$. After biomass saturation, the concentration total metal and $\mathrm{H}^{+}$bound to the solid phase is equal to the maximum concentration of active sites, so the partial derivative in time is zero $\left(d\left(\left\langle C_{\mathrm{H}}\right\rangle+\left\langle C_{\mathrm{M}}\right\rangle\right) / \mathrm{d} t=\mathrm{d} Q_{\max } / \mathrm{d} t=0\right)$ and,

$\frac{\partial y_{\mathrm{T}}(\zeta, \theta)}{\partial \theta}=\frac{1}{P e} \frac{\partial^{2} y_{\mathrm{T}}(\zeta, \theta)}{\partial \zeta^{2}}-\frac{\partial y_{\mathrm{T}}(\zeta, \theta)}{\partial \zeta}$

The new dimensionless variables are:

$y_{\mathrm{b}}(\zeta, \theta)=\frac{C_{\mathrm{b}}(z, t)}{C_{\mathrm{T}_{0}}}, \quad y_{\mathrm{f}}(\zeta, \theta)=\frac{C_{\mathrm{f}}(z, t)}{C_{\mathrm{T}_{0}}}, \quad y_{\mathrm{T}}(\zeta, \theta)=\frac{C_{\mathrm{T}}(z, t)}{C_{\mathrm{T}_{0}}}$,

$\langle y(\zeta, \theta)\rangle=\frac{\langle q(z, t)\rangle}{Q_{\max }}, \quad y^{*}(\zeta, \theta)=\frac{q_{\mathrm{M}}(z, t)}{Q_{\max }}$

The dimensionless parameters are the same considered before, with the exception of the column capacity factor, which is now defined as:

$\xi=\frac{(1-\varepsilon)}{\varepsilon} \rho_{\mathrm{ap}} \frac{Q_{\max }}{C_{\mathrm{T}_{0}}}$

The initial and boundary conditions are:

$\theta=0 \quad y_{\mathrm{b}}(\zeta, 0)=\frac{C_{\mathrm{b}_{0}}}{C_{\mathrm{T}_{0}}}, y_{\mathrm{f}}(\zeta, 0)=\frac{C_{\mathrm{b}_{0}}}{C_{\mathrm{T}_{0}}}, y_{\mathrm{T}}(\zeta, 0)=1,\langle y(\zeta, 0)\rangle=\frac{q_{\mathrm{M}_{0}}}{Q_{\max }}$

$\zeta=0-\frac{1}{P e} \frac{\partial y_{\mathrm{b}}(\zeta, \theta)}{\partial \zeta}+y_{\mathrm{b}}(\zeta, \theta)=0$

$\zeta=\left.1 \quad \frac{\partial y_{\mathrm{b}}(\zeta, \theta)}{\partial \zeta}\right|_{\zeta=1}=\left.\frac{\partial y_{\mathrm{T}}(\zeta, \theta)}{\partial \zeta}\right|_{\zeta=1}=0$

where $C_{\mathrm{T}_{\mathrm{E}}}$ is equal to the molar concentration of feed solution $(0.1 \mathrm{M}$ $\mathrm{HNO}_{3}$ ) and $C_{T_{0}}$ is the sum of the metal and proton concentrations in the interstitial fluid inside the column at the end of the saturation process.

The partial differential Eq. (19), (26) and ODE Eq. (15) in conjunction with the initial and boundary conditions, Eqs. (29-31), were solved by the PDECOL package [35], where $y_{\mathrm{f}}(\zeta, \theta)$ is obtained by 
solving Eq. (17) and the equilibrium is given by the mass action law (Eq. (25))

\subsection{Estimating parameters}

Mathematical models were fitted to the experimental data, obtained from equilibrium studies, by a non-linear regression method (FigSys for Windows from BIOSOFT). Models parameters were obtained by minimizing the sum of the squared deviations between experimental and predicted values. Model goodness was evaluated by standard deviations, sum of square residuals $\left(S_{\mathrm{R}}^{2}\right)$ and regression coefficients $\left(R^{2}\right)$.

\section{Materials and methods}

\subsection{Preparation of the biosorbents}

Algal waste from the agar extraction industry and the same waste granulated with polyacrylonitrile-PAN were used in this study as well as algae Gelidium, which is the raw material for agar extraction. The characteristics and preparation of both materials were presented in previous works $[39,40]$.

\subsection{Preparation of cadmium solutions}

Cadmium(II) solutions were prepared by dissolving a weighed quantity of cadmium(II) chloride dehydrate (Sigma-Aldrich, 99\%) in distilled water. The $\mathrm{pH}$ was controlled by adding $0.01 \mathrm{M} \mathrm{HCl}$ and $0.01 \mathrm{M} \mathrm{NaOH}$ solutions.

\subsection{Sorption studies}

Batch biosorption dynamic experiments were carried out in a 1-1 capacity glass vessel, equipped with a cooling jacket (Grant type VFP) to ensure a constant temperature of $20^{\circ} \mathrm{C}$ during the experiment. The $\mathrm{pH}$ was also monitored and controlled (WTW $538 \mathrm{pH} /$ temperature meter). In a typical batch biosorption kinetic experiment the vessel was filled with 0.51 of distilled water, a known weight of biomass ( $2 \mathrm{~g}$ - algae Gelidium and algal waste, $1 \mathrm{~g}$ - composite material) was added and the suspension was stirred for $20 \mathrm{~min}$ (magnetic stirrer Heidolph MR 3000 operating at $600 \mathrm{rpm})$. Then, the metal solution $(200 \mathrm{mgl})$ was added and the suspension maintained at constant $\mathrm{pH}(6.5,5.3$ or 4$)$ and temperature $\left(T=20^{\circ} \mathrm{C}\right)$. Samples were taken after the addition of metal solution at pre-determined time intervals, ranging from 1 to $10 \mathrm{~min}$ until equilibrium was reached. They were centrifuged (Eppendorf Centrifuge 5410) and the supernatant analysed for $\mathrm{Cd}(\mathrm{II})$.

The equilibrium experiments were conducted in duplicate, using $100 \mathrm{ml}$ Erlenmeyer flasks, at constant values of $\mathrm{pH}(4,5.3$, $6.5)$ and temperature $\left(20^{\circ} \mathrm{C}\right)$. The initial metal concentration was changed between 10 and $200 \mathrm{mg} C d / 1$. A given weight of adsorbent was suspended in $100 \mathrm{ml}$ of a Cd(II) solution and stirred at $100 \mathrm{rpm}$; the $\mathrm{pH}$ was adjusted and controlled by adding $\mathrm{NaOH}$ and $\mathrm{HCl}$ diluted solutions; the temperature was maintained constant by using a HOTTECOLD thermostatic refrigerator. Once equilibrium was reached, $1 \mathrm{~h}$ later, samples were taken out and centrifuged (Eppendorf Centrifuge 5410) and the supernatant analysed for the remaining $\mathrm{Cd}(\mathrm{II})$.

\subsection{Adsorber continuous experiments}

CSTR experiments were conducted in a "carberry" well mixed adsorber (mechanical stirrer Heidolph) with hampers packed with algae Gelidium particles or granules of composite material [36].
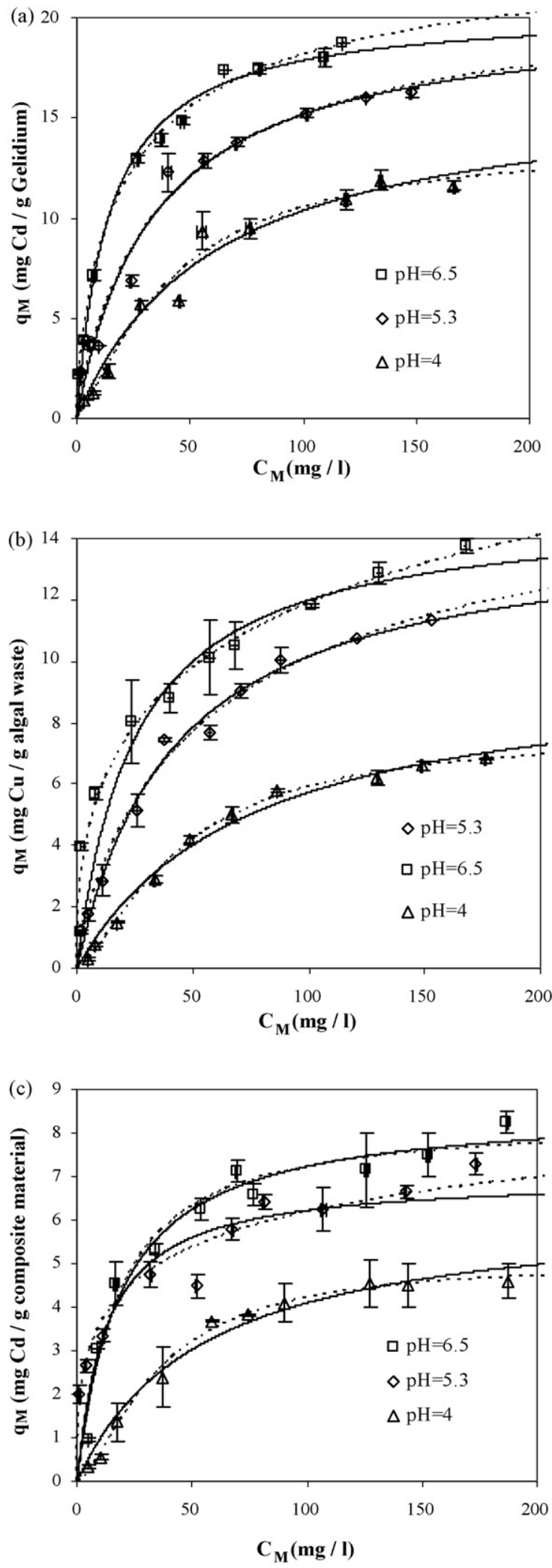

Fig. 1. $\mathrm{Cd}(\mathrm{II})$ biosorption isotherms (average \pm standard deviation) for algae Gelidium (a), algal waste (b) and composite material (c), for different values of $\mathrm{pH}$. (-- -) Langmuir-Freundlich model, (-) Langmuir model. 
Table 1

Model parameters for Langmuir equilibrium model (Eq. (3)) (value \pm standard deviation)

\begin{tabular}{|c|c|c|c|c|c|c|c|c|}
\hline \multirow[t]{2}{*}{ Biosorbent } & \multirow[t]{2}{*}{$\mathrm{pH}$} & \multirow[t]{2}{*}{$T\left({ }^{\circ} \mathrm{C}\right)$} & \multirow[t]{2}{*}{$\mathrm{FI}(\mathrm{M})$} & \multicolumn{3}{|c|}{ Langmuir model } & \multirow[t]{2}{*}{$R^{2}$} & \multirow[t]{2}{*}{$S_{\mathrm{R}}^{2}\left(\mathrm{mg} \mathrm{g}^{-1}\right)^{2}$} \\
\hline & & & & $q_{\mathrm{L}}\left(\mathrm{mgg}^{-1}\right)$ & $K_{\mathrm{L}}\left(\mathrm{l} \mathrm{mg}^{-1}\right) \times 10^{2}$ & $q_{\mathrm{L}} \times K_{\mathrm{L}}\left(\mathrm{lg}^{-1}\right)$ & & \\
\hline \multirow[t]{5}{*}{ Gelidium } & 6.5 & 20 & 0.001 & $20.5 \pm 0.5$ & $6.9 \pm 0.7$ & 1.42 & 0.989 & 0.50 \\
\hline & 5.3 & 20 & 0.001 & $20 \pm 1.0$ & $2.9 \pm 0.4$ & 0.58 & 0.968 & 1.1 \\
\hline & 4 & 20 & 0.001 & $17 \pm 1$ & $1.7 \pm 0.3$ & 0.29 & 0.957 & 0.83 \\
\hline & 5.3 & 35 & 0.001 & $18.3 \pm 0.4$ & $5.4 \pm 0.7$ & 0.99 & 0.987 & 0.37 \\
\hline & 5.3 & 20 & 0.1 & $5.9 \pm 0.4$ & $4 \pm 1$ & 0.24 & 0.883 & 0.37 \\
\hline \multirow[t]{5}{*}{ Algal waste } & 6.5 & 20 & 0.001 & $15 \pm 1$ & $4.0 \pm 0.1$ & 0.60 & 0.930 & 1.17 \\
\hline & 5.3 & 20 & 0.001 & $14.4 \pm 0.7$ & $2.4 \pm 0.3$ & 0.35 & 0.976 & 0.38 \\
\hline & 4 & 20 & 0.001 & $10.0 \pm 0.5$ & $1.4 \pm 0.2$ & 0.14 & 0.987 & 0.10 \\
\hline & 5.3 & 35 & 0.001 & $13 \pm 1$ & $7 \pm 1$ & 0.91 & 0.946 & 0.98 \\
\hline & 5.3 & 20 & 0.1 & $8.2 \pm 0.8$ & $1.3 \pm 0.3$ & 0.11 & 0.946 & 0.22 \\
\hline \multirow[t]{5}{*}{ Composite material } & 6.5 & 20 & 0.001 & $8.6 \pm 0.3$ & $5.3 \pm 0.8$ & 0.46 & 0.937 & 0.34 \\
\hline & 5.3 & 20 & 0.001 & $7.0 \pm 0.4$ & $8 \pm 2$ & 0.56 & 0.823 & 0.51 \\
\hline & 4 & 20 & 0.001 & $6.3 \pm 0.6$ & $1.8 \pm 0.5$ & 0.11 & 0.921 & 0.25 \\
\hline & 5.3 & 35 & 0.001 & $7.5 \pm 0.3$ & $22 \pm 5$ & 1.70 & 0.835 & 0.54 \\
\hline & 5.3 & 20 & 0.1 & $6.6 \pm 0.9$ & $1.2 \pm 0.4$ & 0.08 & 0.900 & 0.24 \\
\hline
\end{tabular}

An acrylic jacket surrounding the CSTR adsorber body allows the operation at constant temperature. The apparent densities of the biosorbents determined by mercury intrusion (PORESIZER 9320), were 1.34 and $0.25 \mathrm{~g} \mathrm{~cm}^{-3}$, respectively, for algae Gelidium and composite material [41]. A known quantity of algae Gelidium or composite material $(\approx 10 \mathrm{~g})$ was placed into the hampers. The solution was pumped (peristaltic pump Ismatec Ecoline VC-380) through the CSTR at $35.5 \mathrm{ml} \mathrm{min}^{-1}$. The flow rate was measured several times during the experiment. CSTR effluent samples were collected regularly and analysed by atomic absorption spectrometry. The $\mathrm{pH}$ of the effluent has been continuously monitored and acquired.

\subsection{Column experiments}

Column experiments were conducted in a glass column (Sigma C 5794) with $2.5 \mathrm{~cm}$ inner diameter and $15 \mathrm{~cm}$ length $(L)$ packed with algae Gelidium particles or granules of the composite material. Temperature was maintained constant by circulating water through an acrylic jacket surrounding the column body. Adjustable plungers, with $20 \mu \mathrm{m}$ selective filters, were attached to the top and bottom of the column. Around $10 \mathrm{~g}$ of algae or composite mate- rial was placed into the column. Cadmium solution $\left(25 \mathrm{mg} \mathrm{l}^{-1}\right)$ was pumped through the column at $4 \mathrm{ml} \mathrm{min}^{-1}$ (peristaltic pump Gilson Minipuls 2). The flow rate was measured several times during the experiment. Samples from the column effluent were collected regularly by a programmable fraction collector (Gilson FC 203B Fraction Collector) and analysed by atomic absorption spectrometry. The effluent $\mathrm{pH}$ was permanently recorded and acquired using a Labview program. After column saturation, a regeneration process using $0.1 \mathrm{M} \mathrm{HNO}_{3}$ at $8 \mathrm{ml} \mathrm{min}^{-1}$ was performed. The sample collection and analysis procedure was the same as for the adsorption step. After elution, the bed was washed with distilled water until the effluent $\mathrm{pH}$ reached the initial loading value. The regenerated bed was reused in a next cycle. The biomass-dried weight was obtained by drying the particles at $50^{\circ} \mathrm{C}$ during 2 days. The column was washed with nitric acid (20\%) and distilled water to remove all the contaminants.

\subsection{Analytical procedure}

$\mathrm{Cd}(\mathrm{II})$ concentrations in the supernatants were determined by Atomic Absorption Spectrometry (GBC 932 Plus AAS). Deuterium background correction was used with a spectral slit width of $0.5 \mathrm{~nm}$.

Table 2

Model parameters for discrete equilibrium model (Eq. (1)) (value \pm standard deviation)

\begin{tabular}{|c|c|c|c|c|c|}
\hline \multirow[t]{2}{*}{ Biosorbent } & \multicolumn{3}{|l|}{ Discrete model } & \multirow[t]{2}{*}{$R^{2}$} & \multirow[t]{2}{*}{$S_{\mathrm{R}}^{2}\left(\mathrm{mmolg}^{-1}\right)^{2}$} \\
\hline & $Q_{\max }\left(\mathrm{mmol} \mathrm{g}^{-1}\right)$ & $\mathrm{p} K_{\mathrm{H}}$ & $\mathrm{p} K_{\mathrm{M}}$ & & \\
\hline Gelidium & $0.17 \pm 0.01$ & $4.32 \pm 0.04$ & $3.61 \pm 0.04$ & 0.980 & $5.3 \times 10^{-5}$ \\
\hline Algal waste & $0.12 \pm 0.01$ & $4.54 \pm 0.03$ & $3.55 \pm 0.03$ & 0.987 & $1.7 \times 10^{-5}$ \\
\hline Composite material & $0.070 \pm 0.002$ & $4.7 \pm 0.1$ & $3.90 \pm 0.07$ & 0.900 & $4.3 \times 10^{-5}$ \\
\hline
\end{tabular}

Table 3

Model parameters for continuous equilibrium model (Eq. (5)) applied to biosorption of $\mathrm{Cu}^{2+}, \mathrm{Pb}^{2+}$ and $\mathrm{Cd}^{2+}$ (value \pm standard deviation)

\begin{tabular}{|c|c|c|c|c|c|c|c|c|c|}
\hline \multirow[t]{2}{*}{ Biosorbent } & \multirow[t]{2}{*}{ Metal } & \multicolumn{6}{|c|}{ Continuous model } & \multirow[t]{2}{*}{$R^{2}$} & \multirow[t]{2}{*}{$S_{\mathrm{R}}^{2}\left(\mathrm{mmolg}^{-1}\right)^{2}$} \\
\hline & & $\log K_{M}^{\prime}$ & $n_{\mathrm{M}}$ & $n_{\mathrm{H}} / n_{\mathrm{M}}$ & $n_{\mathrm{H}} / n_{\mathrm{M}}$ & $n_{\mathrm{M}} / n_{\mathrm{H}}$ & $m_{\mathrm{M}}$ & & \\
\hline Gelidium & $\begin{array}{l}\mathrm{Cu}^{2+} \\
\mathrm{Pb}^{2+} \\
\mathrm{Cd}^{2+}\end{array}$ & $\begin{array}{l}3.1 \pm 0.1 \\
3.9 \pm 0.1 \\
3.0 \pm 0.1\end{array}$ & $\begin{array}{l}0.83 \pm 0.03 \\
0.62 \pm 0.03 \\
0.54 \pm 0.04\end{array}$ & $0.88 \pm 0.08$ & $\begin{array}{l}0.58 \\
0.77 \\
0.89\end{array}$ & $\begin{array}{l}1.7 \\
1.3 \\
1.1\end{array}$ & $\begin{array}{l}0.73 \\
0.55 \\
0.48\end{array}$ & 0.845 & $4.8 \times 10^{-4}$ \\
\hline Algal waste & $\begin{array}{l}\mathrm{Cu}^{2+} \\
\mathrm{Pb}^{2+} \\
\mathrm{Cd}^{2+}\end{array}$ & $\begin{array}{l}3.4 \pm 0.1 \\
4.0 \pm 0.1 \\
3.3 \pm 0.2\end{array}$ & $\begin{array}{l}0.77 \pm 0.04 \\
0.71 \pm 0.04 \\
0.55 \pm 0.05\end{array}$ & $0.69 \pm 0.09$ & $\begin{array}{l}0.70 \\
0.76 \\
0.98\end{array}$ & $\begin{array}{l}1.4 \\
1.3 \\
1.0\end{array}$ & $\begin{array}{l}0.53 \\
0.49 \\
0.38\end{array}$ & 0.896 & $3.1 \times 10^{-4}$ \\
\hline Composite material & $\begin{array}{l}\mathrm{Cu}^{2+} \\
\mathrm{Pb}^{2+} \\
\mathrm{Cd}^{2+}\end{array}$ & $\begin{array}{l}3.3 \pm 0.1 \\
4.3 \pm 0.2 \\
3.2 \pm 0.2\end{array}$ & $\begin{array}{c}1.0 \pm 0.1 \\
0.69 \pm 0.09 \\
0.6 \pm 0.1\end{array}$ & $0.43 \pm 0.09$ & $\begin{array}{l}0.77 \\
1.1 \\
1.3\end{array}$ & $\begin{array}{l}1.3 \\
0.91 \\
0.77\end{array}$ & $\begin{array}{l}0.43 \\
0.30 \\
0.26\end{array}$ & 0.858 & $2.2 \times 10^{-4}$ \\
\hline
\end{tabular}



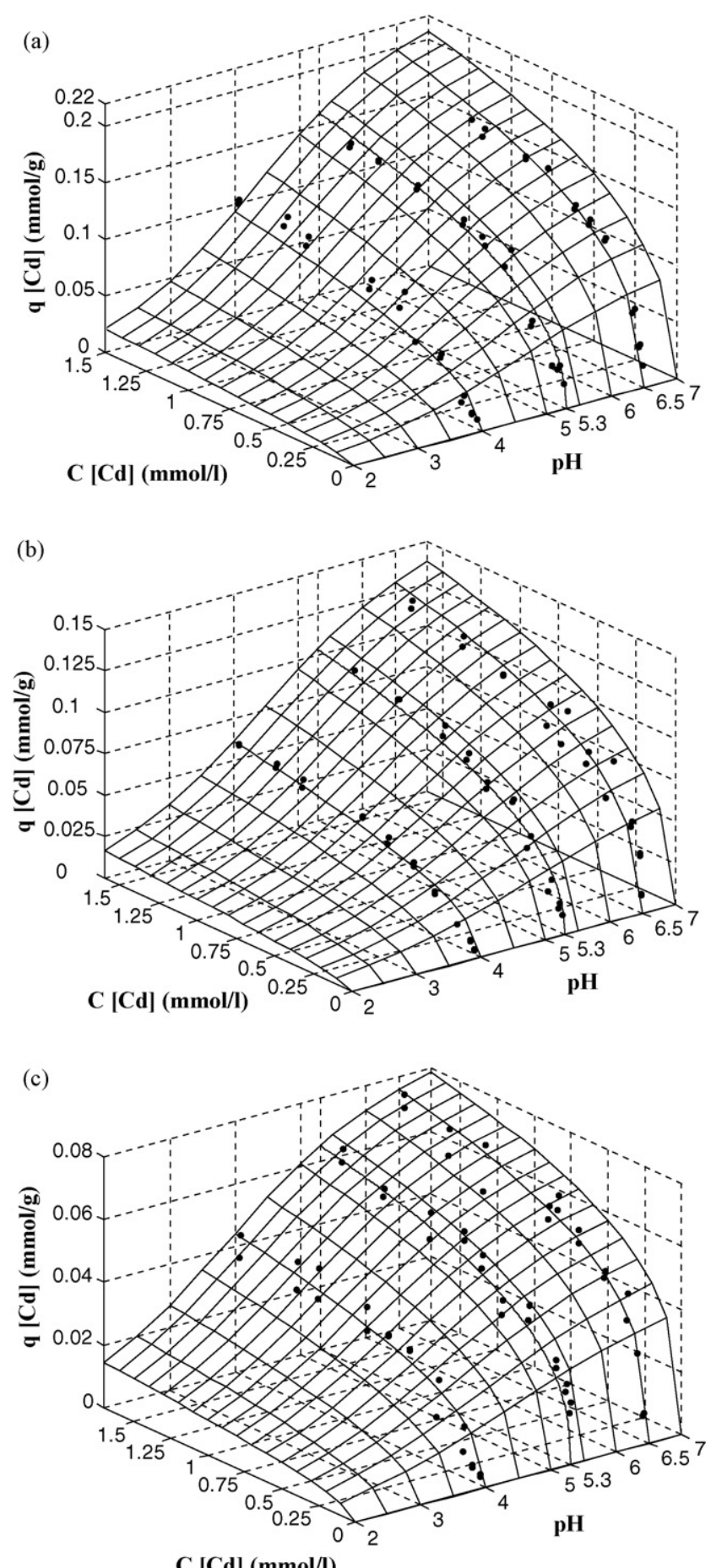

Fig. 2. Cadmium sorption isotherm surface: experimental data and continuous equilibrium model mesh. Solution $\mathrm{pH} 4,5.3$ and 6.5, cadmium concentration 0.0-1.5 $\mathrm{mmol}^{-1}$. Algae Gelidium (a), algal waste (b) and composite material (c).

The working current/wavelength was adjusted to $3.0 \mathrm{~mA} / 228.8 \mathrm{~nm}$, giving a detection limit of $0.2 \mathrm{mg} \mathrm{l}^{-1}$.

\section{Results and discussion}

\subsection{Comparison of biosorbents}

Langmuir and LF adsorption isotherms were fitted to $\mathrm{Cd}(\mathrm{II})$ biosorption equilibrium data as shown in Fig. 1. The models per-

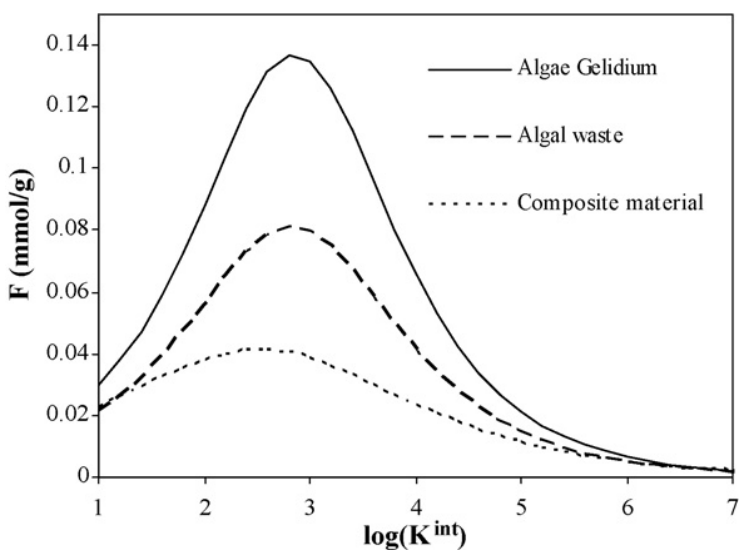

Fig. 3. Affinity distribution function of cadmium for carboxylic groups ( $K^{\text {int }}$ intrinsic equilibrium constant of cadmium ions to the carboxylic groups and $F=$ $\sum_{i} f_{i}\left(\log K_{i, \mathrm{Cd}}^{\text {int }}\right) Q_{\max , i}$, where $f_{i}\left(\log K_{i, \mathrm{Cd}}^{\text {int }}\right)$ is a Quasi-Gaussian distribution suggested by Sips [31] and $Q_{\max }$, overall charge of the carboxylic groups $\left(\mathrm{mmol} \mathrm{g}^{-1}\right)$.

formance was compared by using the F-test. As no significant difference has been found between the two models for $95 \%$ confidence interval, only the Langmuir constants $\left(q_{\mathrm{L}}, K_{\mathrm{L}}\right)$ are reported in Table 1.

The uptake capacities presented in Table 1 indicate that algae Gelidium is the best biosorbent, even for low cadmium concentra-
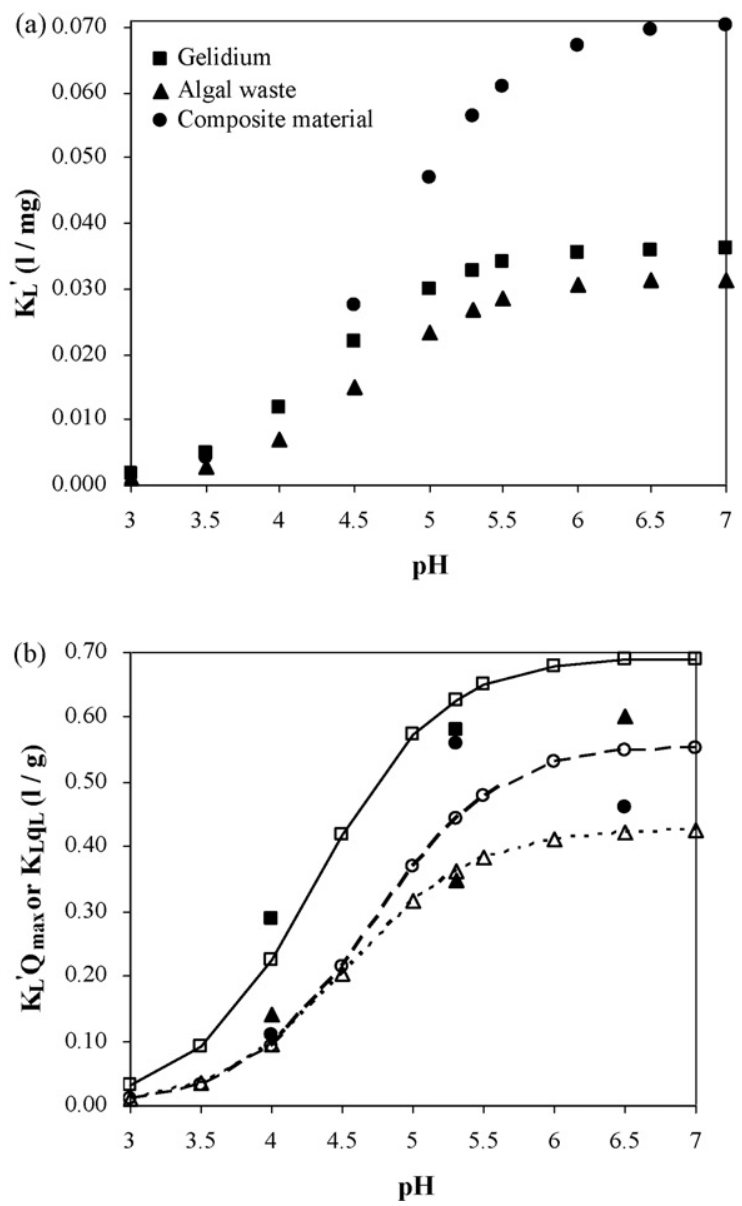

Fig. 4. Effect of the $\mathrm{pH}$ on the Langmuir $K_{\mathrm{L}}^{\prime}$ value (a) and, on $K_{\mathrm{L}}^{\prime} Q_{\max }$ and $K_{\mathrm{L}} q_{\mathrm{L}}$ (b) for algae Gelidium ( $\square$ discrete model, $\square$ Langmuir), algal waste ( $\triangle$ discrete model, 4 Langmuir) and composite material ( $\bigcirc$ discrete model, $\bullet$ Langmuir). 
Table 4

Thermodynamic parameters for the biosorption of $\mathrm{Cd}(\mathrm{II})$ on algae Gelidium, algal waste and composite material

\begin{tabular}{|c|c|c|c|c|c|}
\hline \multirow[t]{2}{*}{ Biosorbent } & \multirow[t]{2}{*}{$\Delta H^{\circ}\left(\mathrm{kJ} \mathrm{mol}^{-1}\right)$} & \multicolumn{2}{|c|}{$\Delta G^{\circ}\left(\mathrm{kJ} \mathrm{mol}^{-1}\right)$} & \multicolumn{2}{|c|}{$\Delta S^{\circ}\left(\mathrm{kJ} \mathrm{mol}^{-1} \mathrm{~K}^{-1}\right)$} \\
\hline & & $T=20^{\circ} \mathrm{C}$ & $T=35^{\circ} \mathrm{C}$ & $T=20^{\circ} \mathrm{C}$ & $T=35^{\circ} \mathrm{C}$ \\
\hline Gelidium & $+31 \pm 10$ & $-19.7 \pm 0.3$ & $-22.3 \pm 0.3$ & $0.17 \pm 0.04$ & $0.17 \pm 0.04$ \\
\hline Algal waste & $+54 \pm 10$ & $-19.3 \pm 0.3$ & $-23.0 \pm 0.4$ & $0.25 \pm 0.03$ & $0.25 \pm 0.03$ \\
\hline Composite material & $+51 \pm 17$ & $-22.2 \pm 0.6$ & $-25.9 \pm 0.6$ & $0.25 \pm 0.05$ & $0.25 \pm 0.05$ \\
\hline
\end{tabular}

tions (higher values of $q_{\mathrm{L}} \times K_{\mathrm{L}}$ ). The same result was obtained for copper [42] and lead [29] biosorption on the same materials.

\subsection{Effect of $p H$}

Since the solution $\mathrm{pH}$ has a significant effect on the adsorption equilibrium, cadmium uptake capacity was evaluated at different $\mathrm{pH}$ (Fig. 1(a), (b) and (c)). The uptake capacity decreases with $\mathrm{pH}$, which suggests competition between hydrogen and cadmium ions. Additionally, carboxylic groups are protonated at $\mathrm{pH}<5\left(\mathrm{p} K_{\mathrm{H}} \approx 5\right)$ [43].

As L and LF isotherm models, in their simple form, do not include the $\mathrm{pH}$ influence on the biosorption process, two equilibrium models were developed, to predict this influence. As metal adsorption was studied at pH below 6.5 and, hydroxyl groups are not dissociated at this $\mathrm{pH}$ range $\left(\mathrm{p} K_{\mathrm{H}}>8.0\right)$, only the contribution of carboxylic groups for binding $\mathrm{Cd}(\mathrm{II})$ has been considered. Both equilibrium models (discrete and continuous) were able to predict the experimental data at different $\mathrm{pH}$ values and cadmium concentrations. The model parameters are presented in Tables 2 and 3, respectively, for the discrete and continuous equilibrium models. The continuous model parameters, $Q_{\max }=0.36,0.23$ and $0.16 \mathrm{mmol} \mathrm{g}^{-1}$, $\mathrm{p} K_{\mathrm{H}}^{\prime}=5.0,5.3$ and 4.4 and $m_{\mathrm{H}}=0.43,0.37$ and 0.33 , respectively, for algae Gelidium, algal waste and composite material, were determined by potentiometric titration [43]. Fig. 2(a), (b) and (c) display the three-dimensional surfaces given by the continuous model and the equilibrium data. The $p$ parameter represents the intrinsic heterogeneity of biosorbent active sites and only depends on the biosorbent. Copper and lead sorption data at different $\mathrm{pH}$ were also fitted, simultaneously with cadmium sorption data, to the continuous model and the model parameters values are presented in Table 3. The higher $p$ value found for algae Gelidium (Table 3) allows to conclude that the carboxylic sites are more homogeneous than those of algal waste and composite material. Metal ions act as Lewis acids by accepting electron pairs from ligands. Class A metal ions, also called hard or nonpolarizable, preferentially form complexes with similar nonpolarizable ligands, particularly oxygen donors, and the binding is mainly ionic. Class B or soft metal ions preferentially bind to polarizable soft ligands $(S)$, to give a rather more covalent bonding [44]. Lead, copper and cadmium ions are considered as borderline metals. Table 3 shows that the affinity increases in the following order $\mathrm{Cd}(\mathrm{II})<\mathrm{Cu}(\mathrm{II})<\mathrm{Pb}$ (II) for all biosorbents. The covalent index (product of the electronegativity square by the sum of the ionic radius and 0.85 , which is an appropriate constant assumed to reflect the radius of $\mathrm{O}$ and $\mathrm{N}$ donor atoms) also increases in the order: $\mathrm{Cd}$ (II) $(5.20)<\mathrm{Cu}$ (II) $(6.32)<\mathrm{Pb}$ (II) (6.61) [45]. In general, the greater the covalent index of a metal ion, the greater its Class B character, and consequently its potential to form covalent bonds with biological ligands. Fig. 3 represents the affinity distribution function for the binding of cadmium to the biosorbents carboxylic groups, obtained by the Sips distribution with parameters from Table 3. Algae Gelidium presents a higher peak than those of algal waste and composite material because it has more carboxylic groups and consequently a higher uptake capacity for cadmium. The affinity distribution function is narrower for algae Gelidium than for algal waste and composite material, which is in agreement with the heterogeneity parameters, $m_{\mathrm{M}}$, in Table 3 (low $m_{\mathrm{M}}$ value for the widest distribution and the highest value for the narrowest distribution). Results suggest that cadmium binds to more homogeneous surface sites in algae Gelidium and to more heterogeneous sites in the others adsorbents.Values of $n_{\mathrm{M}} / n_{\mathrm{H}}>1$ (Table 3) were obtained for all metal ions and biosorbents, except for $\mathrm{Pb}$ (II) $[29,43]$ and $\mathrm{Cd}(\mathrm{II})$ adsorption on the composite material. The results suggest some degree of multi-dentism [32].

The ratio $n_{\mathrm{H}} / n_{\mathrm{M}}$ has a particularly strong influence on the exchange ratio $\left(r_{\mathrm{ex}}\right): r_{\mathrm{ex}}$ changes over the range $0<r_{\mathrm{ex}}<n_{\mathrm{H}} / n_{\mathrm{M}}$, the highest value corresponding to small $p$ (high heterogeneity), low metal concentration and low $\mathrm{pH}$. This happens when most sites are occupied by protons or other cations $\left(\mathrm{Na}^{+}, \mathrm{K}^{+}, \mathrm{Ca}^{2+}, \mathrm{Mg}^{2+}\right)$ and the binding reaction approaches a "normal" ion exchange reaction. Under these conditions, the ratio $n_{\mathrm{H}} / n_{\mathrm{M}}$ represents some kind of reaction stoichiometry [32]. The obtained values (Table 3 ), suggest that cadmium ions adsorption on the composite material has the highest ion exchange character.

The values of $K_{\mathrm{L}}^{\prime}$ (Eq. (2)) decrease with pH, as shown in Fig. 4(a). The same trend was observed for copper [42] and lead adsorption [29], due to metal ions competition with protons. Fig. 4(b) illustrates the $\mathrm{pH}$ influence on the initial Langmuir equation slope, $K_{\mathrm{L}}^{\prime} Q_{\max }$, that represents the driving force for adsorption at low cadmium concentrations. Fig. 4(b) also shows the values of $K_{\mathrm{L}} q_{\mathrm{L}}$ (Table 1) for $\mathrm{pH} 4,5.3$ and 6.5, calculated from the parameters of the Langmuir equation. Those values are similar to those obtained from the

Table 5

Model parameters $\left(k_{\mathrm{p}} \times a_{\mathrm{p}}, \tau_{\mathrm{d}}\right.$ and $\left.D_{\mathrm{h}}\right)$ for linear driving force (LDF) and homogeneous particle diffusion models

\begin{tabular}{|c|c|c|c|c|c|c|c|}
\hline \multirow[t]{2}{*}{ Biosorbent } & \multirow[t]{2}{*}{$C_{i}\left(\mathrm{mg} \mathrm{l}^{-1}\right)$} & \multirow[t]{2}{*}{$\mathrm{pH}$} & \multicolumn{2}{|l|}{ LDF model } & \multicolumn{3}{|c|}{ Homogeneous Diffusion Model } \\
\hline & & & $k_{\mathrm{p}} \times a_{\mathrm{p}}\left(\mathrm{min}^{-1}\right)$ & $\tau_{\mathrm{D}}(\min )$ & $\tau_{\mathrm{p}}(\min )$ & $D_{\mathrm{h}}\left(\mathrm{cm}^{2} \mathrm{~s}^{-1}\right)$ & $\overline{D_{\mathrm{h}}}\left(\mathrm{cm}^{2} \mathrm{~s}^{-1}\right)$ \\
\hline Gelidium & $\begin{array}{r}100 \\
95 \\
84\end{array}$ & $\begin{array}{l}6.5 \\
5.3 \\
4.0\end{array}$ & $\begin{array}{l}0.33 \\
0.33 \\
0.35\end{array}$ & $\begin{array}{l}9.1 \\
9.1 \\
8.6\end{array}$ & $\begin{array}{l}9 \\
9 \\
8.6\end{array}$ & $\begin{array}{l}4.6 \times 10^{-8} \\
4.6 \times 10^{-8} \\
4.8 \times 10^{-8}\end{array}$ & $4.7 \times 10^{-8}$ \\
\hline Algal waste & $\begin{array}{r}100 \\
93 \\
82\end{array}$ & $\begin{array}{l}6.5 \\
5.3 \\
4.0\end{array}$ & $\begin{array}{l}0.75 \\
1.5 \\
0.65\end{array}$ & $\begin{array}{l}4.0 \\
2.0 \\
4.6\end{array}$ & $\begin{array}{l}4 \\
2 \\
5.5\end{array}$ & $\begin{array}{l}1.1 \times 10^{-7} \\
2.1 \times 10^{-7} \\
7.6 \times 10^{-8}\end{array}$ & $1.3 \times 10^{-7}$ \\
\hline Composite material & $\begin{array}{l}78 \\
90 \\
78\end{array}$ & $\begin{array}{l}6.5 \\
5.3 \\
4.0\end{array}$ & $\begin{array}{l}0.30 \\
0.35 \\
0.30\end{array}$ & $\begin{array}{l}10 \\
8.6 \\
10\end{array}$ & $\begin{array}{c}10 \\
8.6 \\
10\end{array}$ & $\begin{array}{l}4.2 \times 10^{-8} \\
4.8 \times 10^{-8} \\
4.2 \times 10^{-8}\end{array}$ & $4.4 \times 10^{-8}$ \\
\hline
\end{tabular}



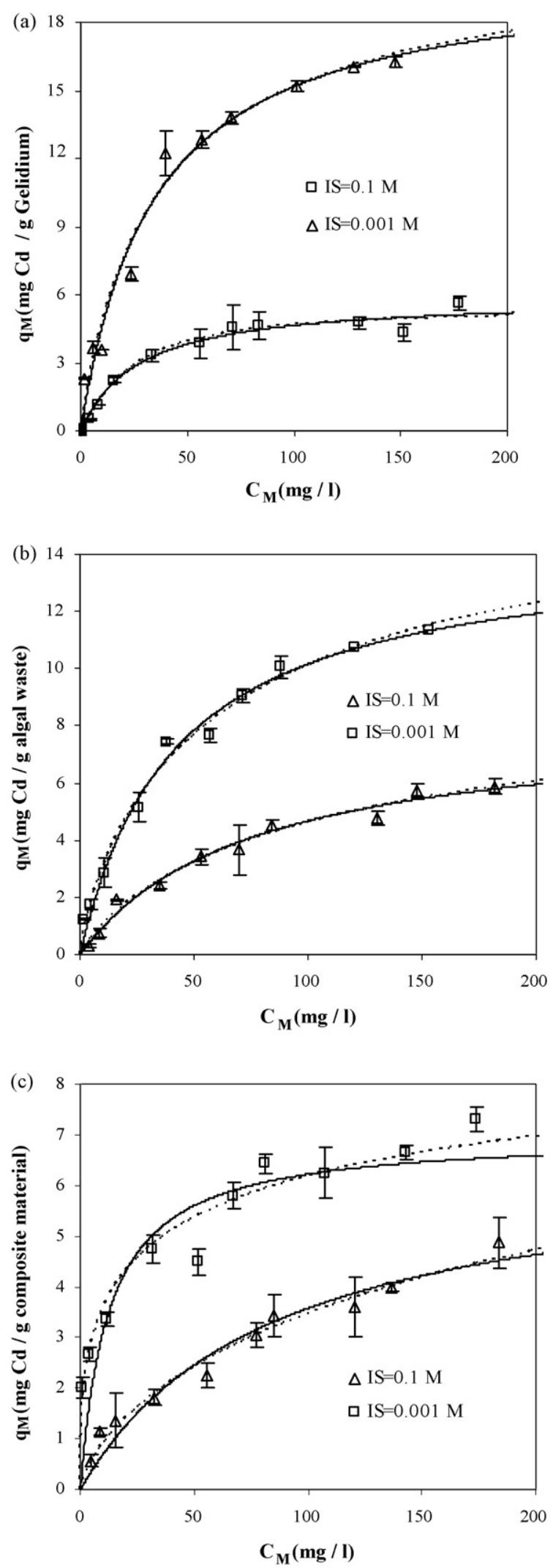

Fig. 5. $\mathrm{Cd}(\mathrm{II})$ biosorption isotherms (average \pm standard deviation) for algae Gelidium (a), algal waste (b) and composite material (c), for different values of ionic strength. (---) Langmuir-Freundlich model, (---) Langmuir model. Equilibrium parameters presented in Table 3.
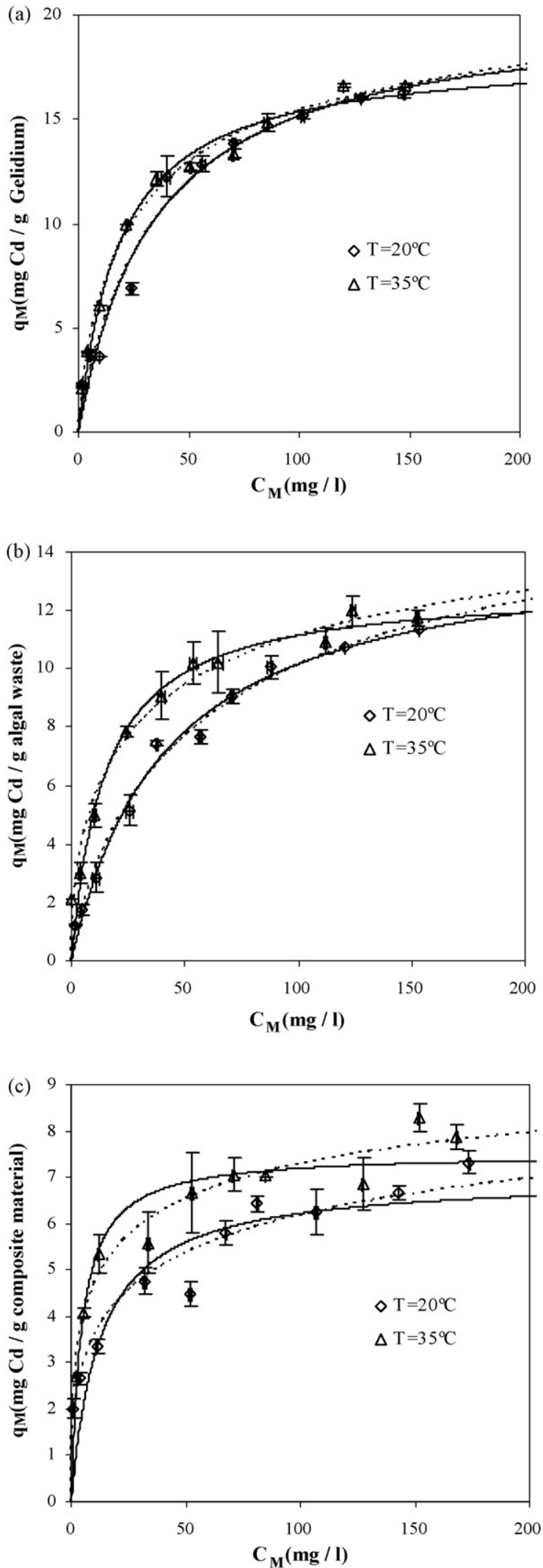

Fig. 6. Cd(II) biosorption isotherms (average \pm standard deviation) for algae Gelidium (a), algal waste (b) and composite material (c), for different values of temperature. (---) Langmuir-Freundlich model, (-) Langmuir model. Equilibrium parameters presented in Table 3. 

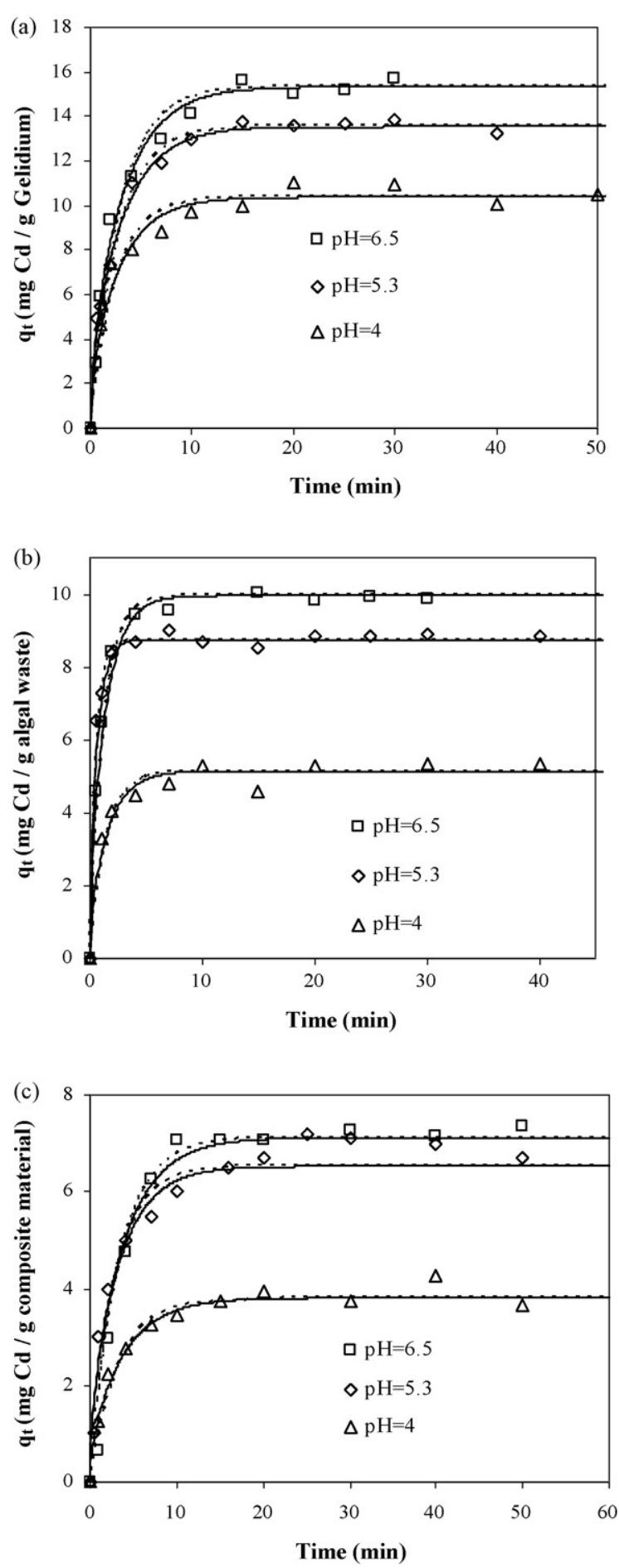

Fig. 7. Evolution of adsorbed Cd(II) concentration ((a) algae Gelidium, algal waste (b) and composite material (c)) with contact time for different values of $\mathrm{pH}$ : experimental data and mass transfer kinetic models ((-- ) linear driving force model, $(-)$ Homogeneous Diffusion Model).

parameters of the discrete model for $\mathrm{pH} 4$. However, for $\mathrm{pH} 5.3$ and 6.5 , the values have a higher deviation, principally for $\mathrm{pH} 6.5$ (algae Gelidium), where $K_{\mathrm{L}}=1.41$ and $K_{\mathrm{L}}^{\prime}=0.69$.

\subsection{Effect of ionic strength (IS)}

The effect of ionic strength on Cd(II) biosorption was studied by changing the electrolyte $\left(\mathrm{KNO}_{3}\right)$ concentration at pH 5.3. Fig. 5(a), (b) and (c) shows that by increasing the ionic strength, the biosorption of Cd(II) decreases by $71.2 \%, 45.3 \%$ and $23.3 \%$, respectively, for algae Gelidium, algal waste and composite material. For high ionic strengths, the negatively charged adsorption sites are surrounded by counter ions (potassium ions) and partially lose their charge, which weakens the contribution of the electrostatic binding to the overall biosorption capacity.

The influence of IS on the metal uptake followed the order $\mathrm{Cd}(\mathrm{II})>\mathrm{Cu}(\mathrm{II})>\mathrm{Pb}$ (II). When the contribution of the covalent binding to the overall biosorption is higher than the electrostatic binding, the influence of the IS is less noticed. This is in agreement with the covalent index, which is higher for lead ions.

\subsection{Temperature effect}

Fig. 6(a), (b) and (c) shows that the equilibrium uptake capacity remains almost the same. However, the biosorption capacity increases with temperature for low cadmium concentrations, suggesting that the metal ions diffusivity increases and/or some active sites become available [46]. The thermodynamic parameters for cadmium adsorption by algae, algal waste and composite material are presented in Table 4 . The negative $\Delta G^{\circ}$ values mean that biosorption is a spontaneous process. $\Delta S^{\circ}>0$ confirms the increased randomness at the solid-solution interface during biosorption and suggests some structural changes in the biosorbent surface during metal binding. The positive $\Delta H^{\circ}$ values mean that the process is endothermic, but the increase in temperature is not economically viable because it has only a slight effect on
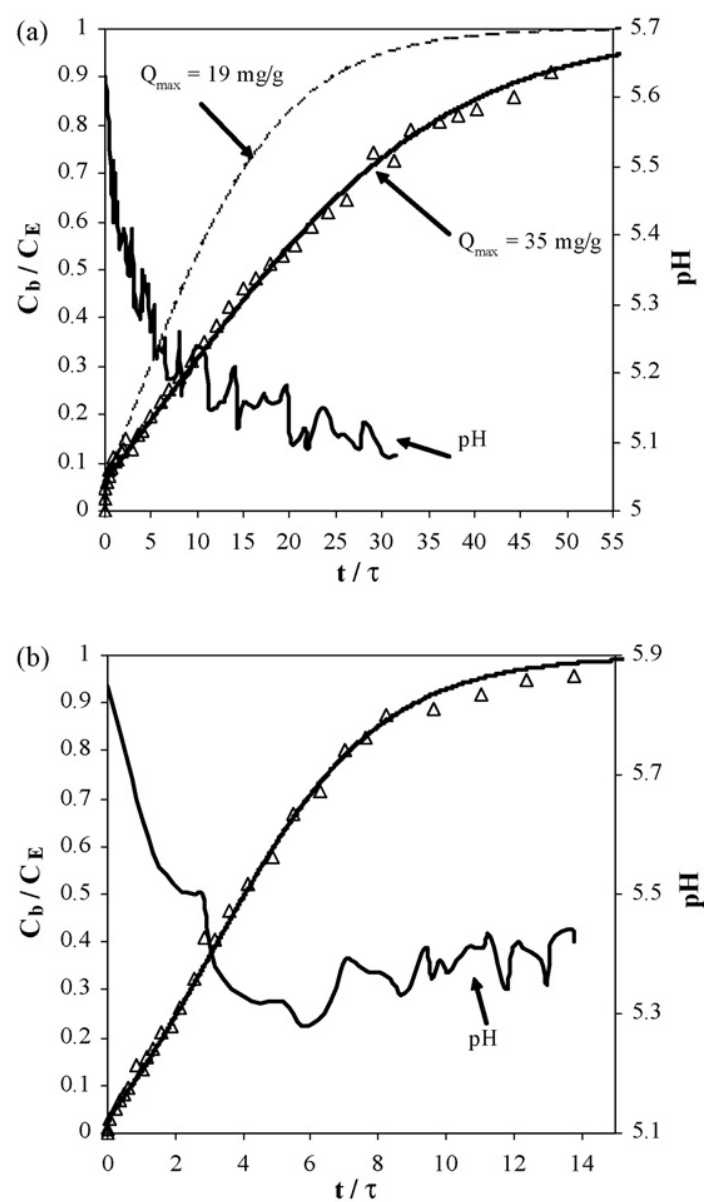

Fig. 8. Experimental data and simulated concentration profiles for continuous biosorption on a CSTR adsorber: (a) algae Gelidium and (b) composite material. 
the uptake capacity. On the other hand, temperature must be in the range $\sim 5-60^{\circ} \mathrm{C}$, because higher temperature can destroy the biomass, losing the active sites [3].

\subsection{Batch kinetics}

Fig. 7(a), (b) and (c) represents the cadmium uptake as a function of time at different $\mathrm{pH}$. The adsorption process is faster on algal waste, suggesting that diffusion resistance is low. During the agar extraction process the porosity of the algal biomass increases, reducing the resistance to intraparticle diffusion [41]. For the preparation of the composite material, the algal waste is immobilized with PAN, which acts as an additional resistance to metal diffusion.

The two mass transfer models (LDF and Homogeneous Diffusion Model) presented in Section 2.3 were able to fit the kinetic experimental data. Fig. 7(a), (b) and (c) compare predicted and experimental data for different $\mathrm{pH}$ values. Model parameters are presented in Table 5. The intraparticle homogeneous diffusion coefficient $\left(D_{\mathrm{h}}\right)$ was obtained considering that particles are plates $0.1 \mathrm{~mm}$ thick (as determined by microscopic observations) [41]. The average diffusion coefficients for cadmium, in the $\mathrm{pH}$ range 4.0-6.5, were $4.7 \times 10^{-8}, 1.3 \times 10^{-7}$ and $4.4 \times 10^{-8} \mathrm{~cm}^{2} \mathrm{~s}^{-1}$, respectively, for algae, algal waste and composite material.

\subsection{Biosorption in CSTR}

Biosorption of cadmium ions by algae and composite material was also studied in a continuous stirred tank adsorber (CSTR) (Fig. 8(a) and (b)), operating in the conditions listed in Table 6. The equilibrium parameters were obtained from the discrete equilibrium model, for the final $\mathrm{pH}$ value measured in the CSTR. The mass transfer model describes the experimental data, although for algae Gelidium the equilibrium was underestimated. The same result was found for copper and lead [36]. The biosorbents used in continuous experiments were previously suspended in distilled water, and submitted to vacuum under agitation, in order to remove air present into the pores and organic matter easily desorbed. Moreover, the biosorbent was washed with distilled water during $2 \mathrm{~h}$, before the beginning of each experiment. After these treatments, the concentration of dissolved organic matter that releases to the solution in the adsorption experiments is low and does not interfere with the adsorption process. The underestimation of the uptake capacities determined in batch system, for algae Gelidium, may be due to metal ions competition between soluble organic matter and particle surfaces, errors in the equilibrium parameters determined by the discrete model at the final $\mathrm{pH}$ of each experiment, $\mathrm{pH}$ variation and algae Gelidium heterogeneity, harvested at different seasons and places. Using the composite material, a small quantity of organic matter is released to the solution due to the active component immobilization process [43], therefore, similar adsorption capacities were obtained in continuous and batch systems.

The model parameters are presented in Table 7. The "knee" of the breakthrough curve is lower for the composite material than for algae Gelidium, which results in a lower film resistance for the composite material (Fig. 8(b)). The homogeneous diffusivity values were obtained from the batch studies (see Table 5). For composite material $N_{\mathrm{f}}>\xi N_{\mathrm{d}}$ (see Table 7) and then we can conclude that the process is intraparticle mass transfer controlled. For algae Gelidium $\xi^{\prime} N_{\mathrm{d}}>N_{\mathrm{f}}$, suggesting that the process is external mass transfer controlled.

The cadmium uptake in the adsorber was 0.11 and $0.06 \mathrm{mmol} \mathrm{g}^{-1}$, respectively, for algae Gelidium and composite material. The protons released to solution by ion exchange with the cadmium ions, calculated from the $\mathrm{pH}$ profile in Fig. 8(a) and (b) $\left(0.073\right.$ and $\left.0.017 \mathrm{mmol} \mathrm{H}^{+}\right)$are much less than the obtained for
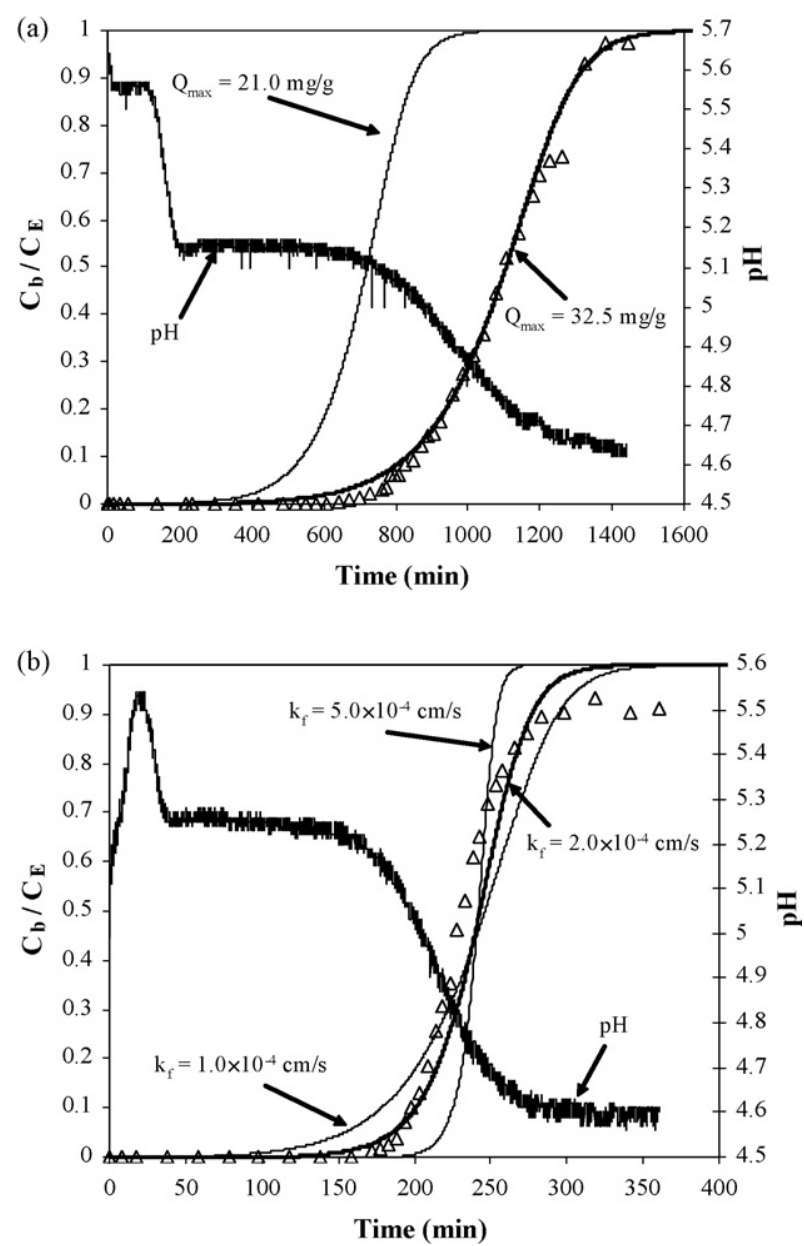

Fig. 9. Experimental data and simulated concentration profiles for continuous biosorption on a column packed bed column: (a) algae Gelidium and (b) composite material.

lead and copper biosorption [36], which indicates that $\mathrm{Cd}^{2+}$ can exchange with other ions $\left(\mathrm{K}^{+}, \mathrm{Na}^{+}, \mathrm{Ca}^{2+}, \mathrm{Mg}^{2+}\right.$ and others), during Cd(II) adsorption.

\subsection{Biosorption in column}

Continuous biosorption by algae Gelidium and composite material was also performed in a packed bed column operating at the conditions presented in Table 8 . The breakthrough time for biosorption on the algae $\left(t_{\mathrm{Bp}}=685 \mathrm{~min}\right)$ is higher than that obtained using the composite material $\left(t_{\mathrm{Bp}}=172 \mathrm{~min}\right)$, which results from the higher uptake capacity of algae $\left(19.8 \mathrm{mg} \mathrm{g}^{-1}\right)$ compared with the composite material $\left(4.9 \mathrm{mg} \mathrm{g}^{-1}\right)$. The length of the mass transfer zone (MTZ) and the fraction of unused bed (LUB) values are presented in Table 9. It can be also observed from Fig. 9(a) and (b), that the final $\mathrm{pH}$ is about 4.6 for both experiments, much higher than the obtained for copper and lead biosorption $(\approx 4.0)$ [43]. As the biosorption capacity for cadmium was found to be higher relatively to copper, for the same operational parameters, we can conclude that the cadmium ions exchange essentially with light metals $\left(\mathrm{K}^{+}\right.$, $\mathrm{Na}^{+}, \mathrm{Ca}^{2+}$ and $\left.\mathrm{Mg}^{2+}\right)$, as observed in the CSTR studies.

Fig. 9(a) and (b) presents the mass transfer model curves. The model fits well the experimental data for both biosorbents, although the equilibrium was underestimated for algae Gelidium as occurred in the CSTR experiments (see Table 9). As shown by Fig. 9(b), higher values of the film diffusion coefficient, decrease 
Table 6

Operation parameters for CSTR experiments at $T=20^{\circ} \mathrm{C}$

\begin{tabular}{|c|c|c|c|c|c|c|c|c|c|c|c|}
\hline Material & No. & $Q\left(\mathrm{ml} \mathrm{min}^{-1}\right)$ & $\mathrm{rpm}$ & $\mathrm{pH}_{\mathrm{SE}}$ & $\mathrm{pH}_{\mathrm{AI}}$ & $\mathrm{pH}_{\mathrm{AE}}$ & $C_{\mathrm{E}}\left(\mathrm{mgl}^{-1}\right)$ & $C_{\text {final }}\left(\mathrm{mg} \mathrm{l}^{-1}\right)$ & $W(\mathrm{~g})$ & $\varepsilon$ & $\tau(\min )$ \\
\hline Gelidium & 1 & 35.5 & 270 & 5.3 & 5.6 & 5.1 & 19.5 & 17.8 & 14.9 & 0.979 & 14.9 \\
\hline Composite material & 2 & 35.5 & 270 & 5.4 & 5.9 & 5.4 & 20.4 & 19.5 & 6.7 & 0.950 & 14.0 \\
\hline
\end{tabular}

Table 7

Mass transfer parameters for biosorption of cadmium in CSTR

\begin{tabular}{|c|c|c|c|c|c|c|c|c|c|c|}
\hline$K_{\mathrm{M}}\left(1 \mathrm{mg}^{-1}\right)$ & $Q_{\max }\left(\mathrm{mgg}^{-1}\right)$ & $\xi$ & $\varepsilon$ & $k_{\mathrm{p}}\left(\mathrm{cm} \mathrm{s}^{-1}\right)$ & $k_{\mathrm{p}} a_{\mathrm{p}}\left(\min ^{-1}\right)$ & $D_{\mathrm{h}}\left(\mathrm{cm}^{2} \mathrm{~s}^{-1}\right)$ & $k_{\mathrm{f}}\left(\mathrm{cm} \mathrm{s}^{-1}\right)$ & $N_{\mathrm{d}}$ & $\xi N_{\mathrm{d}}$ & $N_{\mathrm{f}}$ \\
\hline 0.032 & $\begin{array}{l}35 \\
19\end{array}$ & $\begin{array}{l}\mathbf{2 0 . 5} \\
10.5\end{array}$ & 0.979 & $2.8 \times 10^{-5}$ & 0.34 & $4.7 \times 10^{-8}$ & $\begin{array}{l}\mathbf{4 . 0} \times 10^{-3} \\
6.0 \times 10^{-3}\end{array}$ & 5.0 & $\begin{array}{r}102.5 \\
53.1\end{array}$ & $\begin{array}{l}\mathbf{1 5 . 0} \\
22.5\end{array}$ \\
\hline${ }^{\mathrm{b}} \mathbf{0 . 0 6}$ & 7.9 & 3.6 & 0.950 & $2.6 \times 10^{-5}$ & 0.32 & $4.4 \times 10^{-8}$ & $8.0 \times 10^{-3}$ & 4.6 & 16.5 & 72.8 \\
\hline
\end{tabular}

a Gelidium: $Q_{\max }=19 \pm 1 \mathrm{mg} \mathrm{g}^{-1}, K_{\mathrm{M}}=0.032 \pm 0.0031 \mathrm{mg}^{-1}\left(\mathrm{pH}_{\mathrm{AE}} 5.1\right)$.

b Composite material: $Q_{\max }=7.9 \pm 0.3 \mathrm{mgg}^{-1}, K_{\mathrm{M}}=0.06 \pm 0.01 \mathrm{lmg}^{-1}\left(\mathrm{pH}_{\mathrm{AE}} 5.4\right)$. The values in bold represent the best model parameters.

the breakthrough time, and lower $k_{\mathrm{f}}$ values turn the breakthrough curve steeper. Equilibrium parameters were obtained considering the final $\mathrm{pH}$ of the breakthrough curve, which is the equilibrium $\mathrm{pH}$ inside the column. Biosorption of metal ions by algae Gelidium is accomplished by the release of $\mathrm{H}^{+}, \mathrm{K}^{+}, \mathrm{Na}^{+}, \mathrm{Ca}^{2+}, \mathrm{Mg}^{2+}$ and other ions, due to ion exchange mechanism. Since the metal ions can bind to surface groups by exchange with ions other than $\mathrm{H}^{+}$, most of them not affecting the solution $\mathrm{pH}$, it was not possible to model the $\mathrm{pH}$ profile.

The axial Peclet number based on the particle diameter, $P e_{\mathrm{p}}=u_{\mathrm{i}} d_{\mathrm{p}} / D_{\mathrm{ex}}$ is normally around 2 [47]. This value was used to calculate the Peclet number of the column, $P e=P e_{\mathrm{p}} L / d_{\mathrm{p}}$, which is 3000 and 332, respectively, for algae Gelidium and composite material. As $P e$ is high, principally for algae Gelidium, the axial dispersion could be assumed as negligible. However, those values were considered in the model. As $\xi N_{\mathrm{d}}>N_{\mathrm{f}}$ for both biosorbents, the process is apparently controlled by external diffusion.

After biosorbents saturation with cadmium ions, the desorption process was studied using $\mathrm{HNO}_{3} 0.1 \mathrm{M}$ as eluant. Desorption is a complete and fast process, which allows the biosorbents reutilization in an efficient way.
For high solid to liquid ratio, S/L, desorption is $100 \%$ efficient and cadmium is recovered in small volumes of high concentrated solutions.

Fig. 10(a) and (b) presents simulated curves by the mass transfer model, assuming film and particle resistance, and equilibrium given by the mass action law, adopting for the homogeneous diffusivity coefficient the value found for copper ions $\left(D_{\mathrm{h}}=1.0 \times 10^{-7}\right.$ and $3.0 \times 10^{-7} \mathrm{~cm}^{2} \mathrm{~s}^{-1}$, respectively, for algae Gelidium and composite material) [38] and the selectivity coefficient $\left(K_{\mathrm{H}}^{\mathrm{Cd}}\right)$ determined in batch system also for copper ions. For the composite material the simulated elution curves are displaced to the left relatively to experimental data. This means that the calculated residence time $(\tau)$ is lower than the experimental one. Increasing the apparent density to $0.78 \mathrm{~g} \mathrm{~cm}^{-3}$ the residence time increases. So the simulated elution curve is shifted to right, fitting well the experimental curve (Fig. 10(b)). The apparent density value of $0.78 \mathrm{~g} \mathrm{~cm}^{-3}$ was obtained considering the absence of pores larger than $60 \AA$ diameter [41].

As it was observed in the saturation process, particle mass transfer resistance is lower than the film resistance $\left(\xi N_{\mathrm{d}} \gg N_{\mathrm{f}}\right.$, see Table 10), which means that intraparticle cadmium diffusion is fast and results in an ion exchange process with the high diffusivity

Table 8

Operation parameters for packed bed column experiments at $T=20^{\circ} \mathrm{C}$

\begin{tabular}{|c|c|c|c|c|c|c|c|c|c|c|c|}
\hline Material & No. & Type & $Q\left(\mathrm{ml} \mathrm{min}^{-1}\right)$ & $\mathrm{pH}_{\mathrm{SE}}$ & $\mathrm{pH}_{\mathrm{CI}}$ & $\mathrm{pH}_{\mathrm{CE}}$ & $C_{\mathrm{E}} / C_{\mathrm{Cl}}\left(\mathrm{mg} \mathrm{l}^{-1}\right)$ & $C_{\text {final }}\left(\mathrm{mg} \mathrm{l}^{-1}\right)$ & $W(\mathrm{~g})$ & $\varepsilon$ & $\tau(\min )$ \\
\hline \multirow[t]{2}{*}{ Gelidium } & 3 & S & 4.1 & 5.3 & 5.6 & 4.6 & $45.0 / 0$ & 44.0 & 10.7 & 0.892 & 16.0 \\
\hline & 4 & $\mathrm{E}$ & 8.0 & 0.92 & 4.7 & 0.92 & $0 / 41.8$ & $<0.02$ & 10.7 & 0.892 & 8.2 \\
\hline \multirow[t]{2}{*}{ Composite material } & 5 & $S$ & 4.0 & 5.3 & 5.3 & 4.6 & $45.2 / 0$ & 41.3 & 9.2 & 0.497 & 9.1 \\
\hline & 6 & $\mathrm{E}$ & 8.0 & 1.0 & 4.6 & 1.0 & $0 / 40.0$ & 0.05 & 9.2 & 0.497 & 4.5 \\
\hline
\end{tabular}

Table 9

Mass transfer parameters for biosorption of cadmium in packed bed column

\begin{tabular}{|c|c|c|c|c|c|c|c|c|c|c|c|}
\hline$K_{\mathrm{M}}\left(1 \mathrm{mg}^{-1}\right)$ & $Q_{\max }\left(\mathrm{mgg}^{-1}\right)$ & $\xi$ & $\varepsilon$ & $k_{\mathrm{f}}\left(\mathrm{cm} \mathrm{s}^{-1}\right)$ & $N_{\mathrm{d}}$ & $\xi N_{\mathrm{d}}$ & $N_{\mathrm{f}}$ & $t_{\mathrm{st}}(\mathrm{min})$ & $t_{\mathrm{Bp}}(\min )$ & $\mathrm{MTZ}(\mathrm{cm})$ & LUB (\%) \\
\hline $2.9 \times 10^{-2}$ & $\begin{array}{l}32.5 \\
21.0\end{array}$ & $\begin{array}{l}\mathbf{6 6 . 6} \\
43.1\end{array}$ & 0.892 & $5.5 \times 10^{-4}$ & 5.4 & $\begin{array}{l}359.6 \\
232.7\end{array}$ & 12.8 & 1088 & 685 & 11.1 & 37.0 \\
\hline${ }^{b} \mathbf{3 . 0} \times \mathbf{1 0}^{-2}$ & 7.9 & $\begin{array}{l}25.3 \\
25.3 \\
25.3\end{array}$ & $\begin{array}{l}0.497 \\
\mathbf{0 . 4 9 7} \\
0.497\end{array}$ & $\begin{array}{l}1.0 \times 10^{-4} \\
\mathbf{2 . 0} \times \mathbf{1 0}^{-4} \\
5.0 \times 10^{-4}\end{array}$ & $\begin{array}{l}2.9 \\
2.9 \\
2.9\end{array}$ & $\begin{array}{l}73.3 \\
73.3 \\
73.3\end{array}$ & \begin{tabular}{l|}
11.1 \\
22.2 \\
55.6
\end{tabular} & 240.4 & 172 & 8.5 & 28.5 \\
\hline
\end{tabular}

a Gelidium: $Q_{\max }=19 \pm 2 \mathrm{mg} \mathrm{g}^{-1}, K_{\mathrm{Cd}}=0.026 \pm 0.003 \mathrm{lmg}^{-1}\left(\mathrm{pH}_{\mathrm{CE}} 4.7\right)$.

b Composite material: $Q_{\max }=7.9 \pm 0.3 \mathrm{mgg}^{-1}, K_{\mathrm{Cd}}=0.031 \pm 0.007 \mathrm{lmg}^{-1}\left(\mathrm{pH}_{\mathrm{CE}}=4.6\right)$. The values in bold represent the best model parameters.

Table 10

Mass transfer parameters for desorption of cadmium in packed bed column

\begin{tabular}{|c|c|c|c|c|c|c|c|c|c|}
\hline & $K_{\mathrm{H}}^{\mathrm{Cd}}$ & $Q_{\max }\left(\mathrm{mmolg}^{-1}\right)$ & $\xi$ & $\varepsilon$ & $P_{\mathrm{e}}$ & $k_{\mathrm{f}}\left(\mathrm{cm} \mathrm{s}^{-1}\right)$ & $N_{\mathrm{d}}$ & $\xi N_{\mathrm{d}}$ & $N_{\mathrm{f}}$ \\
\hline Gelidium & 0.93 & 0.36 & 147.2 & 0.892 & 30 & $3.0 \times 10^{-3}$ & 4.91 & 722.1 & 35.8 \\
\hline Composite material & 1.1 & 0.16 & 62.7 & 0.839 & 85 & $3.0 \times 10^{-4}$ & 11.4 & 715.0 & 5.2 \\
\hline
\end{tabular}



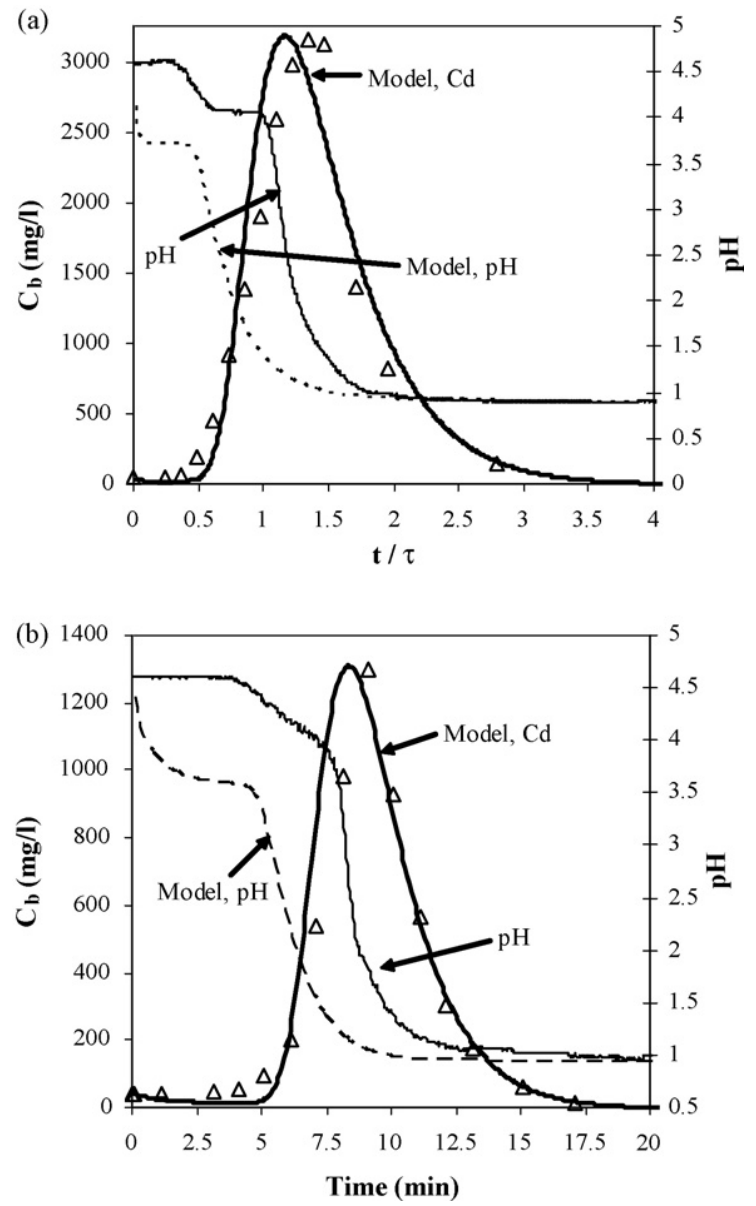

Fig. 10. Experimental data and simulated concentration profiles for continuous desorption on a column packed bed column: (a) algae Gelidium and (b) composite material.

protons. So, the elution process is apparently controlled by the cadmium ions diffusion in the film. Fig. 10(a) and (b) also presents the effluent $\mathrm{pH}$ curve, simulated by the mass transfer model. The simulated profiles of $\mathrm{pH}$ are not a perfect representation of the experimental trend, but indicate that elution is an ion exchange process. The difference between experimental and predicted $\mathrm{pH}$ profile (Fig. 10(a) and (b)) can be due to the fact that in the elution model it was assumed that after biomass saturation the binding sites were only occupied by metal ions and protons. However, some binding groups are occupied by other ions as $\mathrm{Na}^{+}, \mathrm{K}^{+}, \mathrm{Mg}^{2+}, \mathrm{Ca}^{2+}$ and a greater consumption of $\mathrm{H}^{+}$is required to replace these ions. As this consumption was not taken into account, the $\mathrm{pH}$ profile predicted by the model shows a higher decrease compared with the experimental one.

\section{Conclusions}

The studied solid materials can be used as efficient biosorbents to remove cadmium from aqueous solutions. Equilibrium was well described by the discrete and continuous models for different $\mathrm{pH}$ values. These models can predict cadmium uptake at different equilibrium cadmium concentrations and $\mathrm{pH}$, giving a major advantage relatively to Langmuir and Langmuir-Freundlich equations. Cadmium uptake is $\mathrm{pH}$-dependent, decreasing with the $\mathrm{pH}$. The presence of other cations, such as $\mathrm{K}^{+}$, decreases the contribution of the electrostatic binding and negatively affects to the overall cadmium uptake. Temperature has a minor effect on cadmium uptake.
Cadmium affinity for carboxylic sites given by the Sips distribution shows a narrow distribution for algae and algal waste, but it is wide for the composite material.

Cadmium biosorption kinetics was fast and high affinity for the carboxylic groups was found. CSRT studies and fixed bed studies showed that both systems can be used to remove continuously cadmium ions in aqueous solution. Regeneration of the biosorbents was also achieved in a fast way using strong acid.

\section{Acknowledgements}

Financial support for this work was in part provided by national research grant FCT/POCTI/AMB/57616/2004 and by LSRE financing by FEDER/POCI/2010, for which the authors are thankful. V. Vilar acknowledges his Ph.D. scholarship by FCT (SFRH/BD/7054/2001).

\section{References}

[1] J.W. Patterson, Industrial Wastewater Treatment Technology, second ed., Butterworth, Boston, 1985.

[2] T.R.N. Roman, É.G.d. Lima, R. Azoubel, F. Batigália, Toxicidade do cádmio no homem, HB Científica 9 (1) (2002) 43-48.

[3] B. Volesky, Sorption and biosorption, 1st ed., BV Sorbex, Inc., Quebec, 2003.

[4] B. Volesky, Biosorption of Heavy Metals, CRC Press, Montreal, 1990.

[5] P.G. Wightman, J.B. Fein, Ternary interactions in a humic acid-Cd-bacteria system, Chem. Geol. 180 (2001) 55-65.

[6] N. Rangsayatorn, E.S. Upatham, M. Kruatrachue, P. Pokethitiyook, G.R. Lanza, Phytoremediation potential of Spirulina (arthrospira) platensis: biosorption and toxicity studies of cadmium, Environ. Pollut. 119 (2002) 45-53.

[7] A. Kapoor, R. Viraraghavan, Removal of heavy metals from aqueous solutions using immobilized fungal biomass in continuous mode, Water Res. 32 (6) (1998) 1968-1977.

[8] K. Chojnacka, A. Chojnacki, H. Górecka, Biosorption of $\mathrm{Cr}^{3+}, \mathrm{Cd}^{2+}$ and $\mathrm{Cu}^{2+}$ ions by blue-green algae Spirulina sp.: Kinetics, equilibrium and the mechanism of the process, Chemosphere 59 (2005) 75-84.

[9] W.-Y. Lee, W.-X. Wang, Metal accumulation in the green macroalga Ulva fasciata: effects of nitrate, ammonium and phosphate, Sci. Total Environ. 278 (2001) $11-22$.

[10] E. Fourest, B. Volesky, Alginate properties and heavy metal biosorption by marine algae, Appl. Biochem. Biotechnol. 67 (1) (1997) 33-44.

[11] Z.R. Holan, B. Volesky, Biosorption of Cd by biomass of marine algae, Biotechnol. Bioeng. 41 (1993) 819-825.

[12] T.A. Davis, B. Volesky, R.H.S.F. Vieira, Sargassum seaweed as biosorbent for heavy metals, Water Res. 34 (2000) 4270-4278.

[13] M.M. Figueira, B. Volesky, V.S.T. Ciminelli, F.A. Roddick, Biosorption of metals in brown seaweed biomass, Water Res. 34 (1) (2000) 196-204

[14] W. Ma, J.M. Tobin, Development of multimetal binding model and application to binary metal biosorption onto peat biomass, Water Res. 37 (2003) 3967-3977.

[15] D. Zhou, L. Zhang, J. Zhou, S. Guo, Cellulose/chitin beads for adsorption of heavy metals in aqueous solution, Water Res. 38 (2004) 2643-2650.

[16] R.J.E. Martins, R. Pardo, R.A.R. Boaventura, Cadmium(II) and zinc(II) adsorption by the aquatic moss Fontinalis antipyretica: effect of temperature, ph and water hardness, Water Res. 38 (2004) 693-699.

[17] Y.S. Ho, C.C. Wang, Pseudo-isotherms for the sorption of cadmium ion onto tree fern, Proc. Biochem. (2003) 1-5.

[18] P.A. Marques, H.M. Pinheiro, J.A. Teixeira, M.F. Rosa, Removal efficiency of $\mathrm{Cu}^{2+}$ $\mathrm{Cd}^{2+}$ and $\mathrm{Pb}^{2+}$ by waste brewery biomass: $\mathrm{pH}$ and cation association effects, Desalination 124 (1999) 137-144.

[19] A. Leusch, Z.R. Holan, B. Volesky, Biosorption of heavy metals ( $\mathrm{Cd}, \mathrm{Cu}, \mathrm{Ni}, \mathrm{Pb}, \mathrm{Zn}$ ) by chemically-reinforced biomass of marine algae, J. Chem. Technol. Biotechnol. 62 (3) (1995) 279-288.

[20] D.C.K. Ko, J.F. Porter, G. McKay, Film-pore diffusion model for the fixed-bed sorption of copper and cadmium ions onto bone char, Water Res. 35 (16)(2001) 3876-3886.

[21] D.C.K. Ko, J.F. Porter, G. McKay, Mass transport model for the fixed bed sorption of metal ions on bone char, Ind. Eng. Chem. Res. 42 (2003) 3458-3469.

[22] K. Vijayaraghavan, J. Jegan, K. Palanivelu, M. Velan, Removal of nickel(II) ions from aqueous solution using crab shell particles in a packed bed up-flow column, J. Hazard. Mater. B 113 (2004) 223-230.

[23] Z. Zulfadhly, M.D. Mashitah, S. Bhatia, Heavy metals removal in fixed-bed column by the macro fungus Pycnoporus sanguineus, Environ. Pollut. 112 (2001) 463-470.

[24] Q. Yu, P. Kaewsarn, Fixed-bed study for copper (II) removal from aqueous solutions by marine alga Durvillaea potatorum, Environ. Technol. 20 (1999) 1005-1008.

[25] S.V. Dimitrova, Use of granular slag columns for lead removal, Water Res. 36 (2002) 4001-4008

[26] M.M. Figueira, B. Volesky, K. Azarian, V.S.T. Ciminelli, Biosorption column performance with a metal mixture, Environ. Sci. Technol. 34 (2000) 4320-4326. 
[27] F. Sebesta, Preparation of granular forms of powdered materials for their application in column packed beds, Nat. Microporous Mater. Environ. Technol.(1999) 473-484.

[28] A.I. Zouboulis, K.A. Matis, M. Loukidou, F. Sebesta, Metal biosorption by panimmobilized fungal biomass in simulated wastewaters, Colloids Surf. A 212 (2003) 185-195.

[29] V.J.P. Vilar, C.M.S. Botelho, R.A.R. Boaventura, Kinetics and equilibrium modelling of lead uptake by algae Gelidium and algal waste from agar extraction industry, J. Hazard. Mater. 143 (1-2) (2007) 396-408.

[30] I. Langmuir, The adsorption of gases on plane surfaces of glass, mica and platinum. J. Am. Chem. Soc. 40 (1918) 1361-1403.

[31] R. Sips, On the structure of a catalyst surface, J. Chem. Phys. 16 (1948) 490-495.

[32] D.G. Kinniburgh, W.H. van Riemsdijk, L.K. Koopal, M. Borkovec, M.F. Benedetti, M.J. Avena, Ion binding to natural organic matter: competition, heterogeneity, stoichiometry and thermodynamic consistency, Colloids Surf. A 151 (1999) 147-166.

[33] A.E. Rodrigues, Elementos sobre a teoria de percolação, Luanda, 1974.

[34] A.E. Rodrigues, D. Tondeur, Percolation Processes, Theory and Applications, SIJTHOFF \& NOORDHOFF, Maryland, USA, 1981.

[35] N. Madsen, R. Sincovec, Pdecol: general collocation software for partial differential equations, ACM Trans. Math. Soft. 5 (3) (1979) 326-351.

[36] V.J.P. Vilar, C.M.S. Botelho, R.A.R. Boaventura, Lead and copper biosorption by marine red algae Gelidium and composite material in a CSTR ("Carberry" Type) Chem. Eng. J. 138 (1-3) (2008) 249-257.

[37] A.C. Hindmarsh, Odepack, a Systematized Collection of Ode Solvers in Scientific Computing, Scientific Computing, Amsterdam, 1983.
[38] V.J.P. Vilar, C.M.S. Botelho, R.A.R. Boaventura, Copper desorption from Gelidium algal biomass, Water Res. 41 (7) (2007) 1569-1579.

[39] V.J.P. Vilar, C.M.S. Botelho, R.A.R. Boaventura, Equilibrium and kinetic modelling of Cd(II) biosorption by algae Gelidium and agar extraction algal waste, Water Res. 40 (2) (2006) 291-302.

[40] V.J.P. Vilar, F. Sebesta, C.M.S. Botelho, R.A.R. Boaventura, Equilibrium and kinetic modelling of $\mathrm{Pb}^{2+}$ biosorption by granulated agar extraction algal waste, Proc. Biochem. 40 (10) (2005) 3276-3284.

[41] V.J.P. Vilar, C.M.S. Botelho, R.A.R. Boaventura, Methylene blue adsorption by algal biomass based materials: biosorbents characterization and process behaviour, J. Hazard. Mater. 127 (1-2) (2007) 120-132.

[42] V.J.P. Vilar, C.M.S. Botelho, R.A.R. Boaventura, Copper removal by algae gelidium, agar extraction algal waste and granulated algal waste: kinetics and equilibrium, Biores. Technol. 99 (4) (2007) 750-762.

[43] V.J.P. Vilar, Uptake of metal ions in aqueous solution by algal waste from agar extraction industry. Ph.D. Thesis, Faculty of Engineering University of Porto, Porto, 2006.

[44] R.G. Pearson, Hard and soft acids and bases, J. Am. Chem. Soc. 85 (1963) 3533-3539.

[45] E. Nieboer, W.A.E. McBryde, Free-energy relationships in coordination chemistry. III. A comprehensive index to complex stability, Can. J. Chem. 51 (1973) $2512-2524$.

[46] S. Al-Ashed, Z. Duvnjak, Adsorption of copper and chromium by Aspergillus carbonarius, Biotechnol. Prog. 11 (1995) 638-642.

[47] G.F. Froment, K.B. Bischof, Chemical Reactor Analysis and Design, 2nd ed., John Wiley \& Sons, New York, 1990. 